Krabbendam et al: Knoydart Structure \& Stratigraphy

\title{
Structure and stratigraphy of the Morar Group in Knoydart, NW Highlands: implications for the history of the Moine Nappe and stratigraphic links between the Moine and Torridonian successions
}

\author{
M. Krabbendam *, A.G. Leslie \& K.M. Goodenough \\ British Geological Survey, Murchison House, West Mains Road, Edinburgh EH9 3LA, UK \\ * Corresponding author: email: mkrab@bgs.ac.uk
}

\begin{abstract}
The Caledonian Orogen in Northern Scotland comprises two major thrust nappes: the Moine and the Sgurr Beag Nappe. The Moine Nappe contains early Neoproterozoic Morar Group rocks (Moine Supergroup) and basement inliers. This paper describes the structure and stratigraphy of the Knoydart peninsula, a key area within the southern Moine Nappe. The geology of Knoydart is dominated by a thick internally coherent sequence of Morar Group rocks. This sequence is shown to be deformed by large-scale, west-vergent and west-facing Caledonian (early Palaeozoic) folds that represent D2 within the southern Moine Nappe.

Subsequent D3 deformation led to refolding or tightening of F2 folds, so that the major Morar Antiform is in essence a composite F2/F3 fold. F2 and F3 folds are broadly co-axial, but F3 folds have steeper axial planes.

The F2/F3 folds refold a regional-scale, originally recumbent, isoclinal F1 fold nappe of probable Knoydartian (mid-Neoproterozoic) age. The F1 fold nappe is cored by a thin sliver of basement gneiss; the lower limb comprises migmatitic Morar Group rocks, exposed in the Morar Window. The upper limb of the F1 fold nappe occupies most of Knoydart and is stratigraphically coherent and right-way-up. Within this sequence, the upper unit of the Lower Morar Psammite is barely deformed, preserving trough-cross-bedding and largescale channels in thick beds. This suggests braided river deposition, similar to the Torridon Group west of the Moine Thrust and the Morar Group in the northern part of the Moine Nappe. On the basis of lithological similarity and stratigraphic disposition, it is suggested that the lowermost part of the Morar Group in Knoydart correlates with the Neoproterozoic Sleat Group on Skye.
\end{abstract}




\section{Introduction}

The Caledonian Orogen in the Northern Highlands terrane of Scotland is dominated by two major thrusts: the lower Moine Thrust in the west and the higher Sgurr Beag Thrust farther east (Fig. 1a). The Moine Nappe, bounded by these two thrusts, is mainly composed of meta-sedimentary rocks of the early Neoproterozoic Morar Group, the lowest tectono-stratigraphic unit of the Moine Supergroup (Holdsworth et al. 1994; Strachan et al. 2002). Throughout the Moine nappe a number of basement gneiss inliers occur, of which the GlenelgAttadale Inlier (Ramsay 1958; Storey 2008) is the largest (Fig. 1b). A coherent stratigraphic sequence of the Morar Group has been established in Knoydart and neighbouring Morar (Ramsay and Spring 1962; Johnstone et al. 1969; Glendinning 1988; Bonsor \& Prave 2008). This stratigraphy can be broadly correlated with the Morar Group sequence in Ross-shire and Sutherland farther north. Stratigraphical and sedimentological studies of the Morar Group in Ross-shire have recently recognised a transition from braided river to shallow marine deposition (Bonsor et al. 2010; 2012). The lower part of the Morar Group in Ross-shire has been correlated with the Torridon Group west of the Moine Thrust, on the basis of sedimentology, stratigraphy, detrital zircon geochronology and geochemistry (Krabbendam et al. 2008; 2011).

The Moine Supergroup in the Northern Highlands has been affected by at least three orogenic episodes (oldest to youngest): the Knoydartian, Grampian and Scandian episodes (Strachan et al. 2002; Chew \& Strachan 2014); with the latter two comprising the Caledonian orogeny (e.g. McKerrow et al. 2000). Knoydart is the type area of the Knoydartian Orogeny (or orogenies) dated between 820 and 740 Ma, a somewhat enigmatic and poorly constrained mid-Neoproterozoic event or events (e.g. Giletti, 1961; van Breemen et al. 1974; Rogers et al. 1998; Vance et al. 1998; Tanner \& Bluck 1999; Oliver 2002; Tanner \& Evans 2003; Cutts et al. 2010; Cawood et al. in press). Grampian (c. 475-460 Ma) deformation and magmatism appears to be mainly restricted to the higher Sgurr Beag and Naver nappes (Kinny et al. 1999; Cutts et al. 2010). Scandian (c. 440- $420 \mathrm{Ma}$ ) deformation was the last major phase, affecting much of the Moine succession and culminating in major displacement along the Moine Thrust (Freeman et al. 1998; Kinny et al. 2003; Alsop et al. 2010; Goodenough et al. 2011). However, the separation between 'Grampian' and 'Scandian' events may not be so clear-cut as previously thought, as there is increasing evidence of tectonothermal activity around 450 Ma specifically in the southern Moine Nappe (Goodenough, 2011; Bird et al. 2013, Cawood et al. in press),

Previous studies have examined the complex structural geometry and evolution of Knoydart and Morar (Fig. 1b; Spring 1961; Ramsay \& Spring 1962; Poole \& Spring 1974; Powell 1966, 1974). However, there is still uncertainty which structures and deformation phases within the Moine and Sgurr Beag nappes were formed during which orogenic episode (e.g. Tanner \& Bluck 1999; Storey et al. 2004). 



Fig.1. (a) Simplified geological map of the Northern Highlands, showing main thrust sheets. Box indicates Figure $1 \mathrm{~b}$. (b) Simplified geological map of Knoydart and surrounding area.

Thrusts: AT = Achness Thrust; KT = Kishorn Thrust; MT = Moine Thrust; NT = Naver Thrust; SBT = Sgurr Beag Thrust; SkT = Skinsdale Thrust.

Folds: AA = Airor Antiform; BMA = Beinn Mhialairidh Antiform; BSS = Beinn Sgritheall Synform; CA = Crionach Antiform; GSS = Glen Shian Synform; LAS = Lochalsh Syncline; LHA = Loch Hourn Antiform; MA = Morar Antiform. Note locations of samples that have yielded Knoydartian ages.

During revision mapping of the Knoydart peninsula (Fig. 2), the authors found a number of structures and structural relationships that, with the benefit of more modern structural methods and concepts, appear to be at variance with published structural models. Specifically these are: (i) the structural age of major folds such as the Loch Hourn Anticline and the Morar Antiform (Fig. 2), (ii) the presence or absence of an eastfacing 'Knoydart fold' and (iii) the presence or absence of the so-called 'Knoydart Slide' or thrust, separating a ‘Knoydart Nappe’ from the Moine Nappe (Poole \& Spring 1974; Powell 1974; Barr et al. 1986). The new evidence and analysis presented here clarify the internal structure of the southern part of the Moine Nappe, and also provide constraints as to the relative contribution of the different orogenic episodes that affected the Moine Nappe. These new observations also have a bearing on possible stratigraphical correlations of the Morar Group with the early Neoproterozoic Sleat and Torridon sequences west of the Moine Thrust. 


\section{Geological setting of Knoydart peninsula}

The Knoydart peninsula lies wholly within the Moine Nappe which overlies the Caledonian brittle-ductile Moine Thrust (Fig. 1). The area is structurally overlain by the ductile ( amphibolite-facies) Sgurr Beag Thrust (Tanner 1971; Roberts et al. 1987). To the west, the Caledonian Foreland and the Moine Thrust Zone in the footwall of the Moine Thrust contains a tripartite sequence comprising Archaean gneiss basement (the Lewisian Gneiss Complex); Meso- to Neoproterozoic siliciclastic sedimentary rocks (the Stoer, Sleat and Torridon groups); and a Cambro-Ordovician sedimentary succession (Peach et al. 1907; Park et al. 2002; Stewart 2002; Kinnaird et al. 2007). The Moine Thrust Zone on the Isle of Skye, west of Knoydart, is dominated by Sleat and Torridon group strata folded in the large-scale recumbent Lochalsh Syncline (e.g. Bailey 1955; Coward \& Potts 1985). The Moine Nappe in the hangingwall of the Moine Thrust comprises a large (>50 x $200 \mathrm{~km}$ ) outcrop of metasedimentary Morar Group rocks, together with a number of basement inliers, including the Glenelg-Attadale Inlier, all deformed under amphibolite-facies conditions (e.g. Barr et al. 1986; Strachan et al. 2010). The Moine Nappe contains a number of large-scale fold structures that broadly trend north-south in Knoydart and Morar (Fig. 2), and also farther north in the Fannichs area; these structures fold the overlying Sgurr Beag Thrust (Poole and Spring 1974; Powell 1974; Krabbendam et al. 2011). Farther south-east such folding intensifies into the 'Northern Highlands Steep Belt' (Roberts \& Harris 1983; Roberts et al. 1987).

\section{Morar Group}

In its type area, the Morar Group is a tripartite succession of Lower Morar Psammite Formation - Morar Pelite Formation - Upper Morar Psammite Formation (see Fig. 3; Richey \& Kennedy 1939; Johnstone et al. 1969; Holdsworth et al. 1994). In Ross-shire, a coherent Morar Group sequence with a restored stratigraphic thickness of up to $9 \mathrm{~km}$ has been recognised (Krabbendam et al. 2011; Bonsor et al. 2010, 2012). Despite amphibolite-facies metamorphic overprint, the gross stratigraphy can be correlated from its type area in Morar northwards to Ross-shire (Fig. 3; Johnstone et al. 1969; Mendum 2009).

In Knoydart, Ramsay \& Spring (1962) subdivided the Lower Morar Psammite Formation into four units, from base to top: the Basal Pelite, Arnisdale Psammite, Rubha Ruadh Semipelite and Barrisdale Psammite (Fig. 3). This succession was confirmed by our recent work, and is described in more detail below. Deposition of the Morar Group occurred after c.1000-980 Ma, as indicated by the youngest recorded detrital zircons (Friend et al. 2003; Kirkland et al. 2008). The minimum age for deposition is indirectly constrained by the c. 870 Ma emplacement age of the West Highland Granite Gneiss and related metagabbros in the Sgurr Beag nappe (Friend et al. 1997; Millar 1999) these meta-igneous bodies intrude into the Glenfinnan and Loch Eil group rocks, generally regarded as younger than the Morar Group (Holdsworth et al. 1994). 


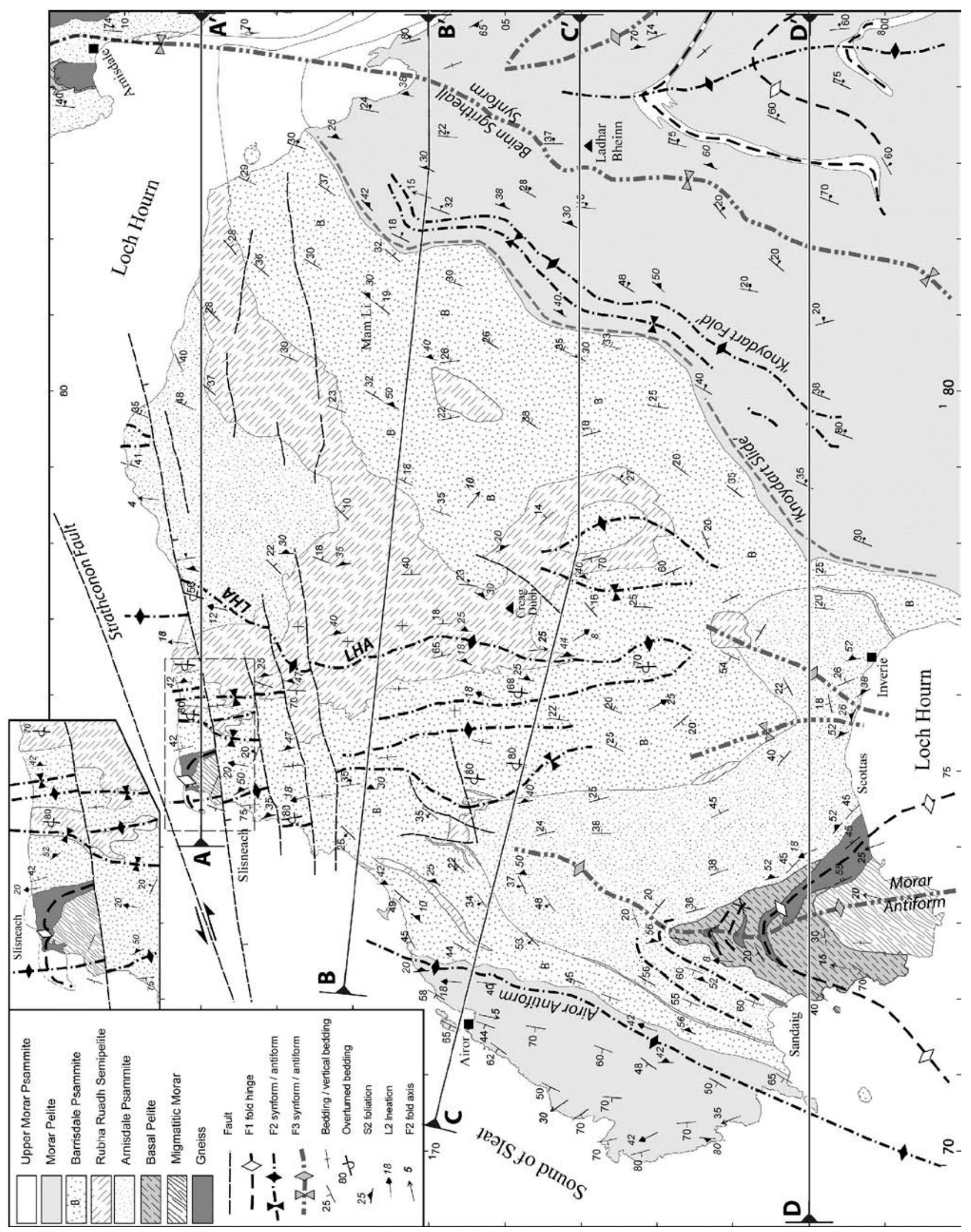

Fig. 2. Geological map of Knoydart. After Geological Survey of Scotland (1909), British Geological Survey (1971, 1984), Powell (1974); Mendum (2009) and mapping by the authors 


\section{Lewisianoid Basement : Western and Eastern Glenelg gneiss}

Numerous basement gneiss inliers occur throughout the Moine Nappe, some of which have Archaean-age protoliths similar to the Lewisian Gneiss Complex in the Forelabds (Friend et al. 2008). Thin slivers of gneiss occur in NW and SW Knoydart (Fig. 2, 4a) and farther south in Morar (Lambert and Poole 1964; Poole and Spring 1974). North of Knoydart is the Glenelg-Attadale Inlier (Peach et al. 1910; Ramsay 1958, Sanders et al. 1984, Storey 2008). This large inlier comprises two very different 'assemblages': the Western Unit and Eastern Unit of the Glenelg-Attadale Inlier (Storey 2008). Because the gneisses occur in numerous separate individual inliers (sensu stricto: outcrops of older rocks surrounded by younger rocks, e.g. Bates \& Jackson, 1987), we prefer the more general terms Eastern and Western Glenelg gneiss. The Western Glenelg gneiss comprises felsic and mafic orthogneisses, commonly with well-preserved agmatitic textures; paragneiss is absent. It experienced high-pressure granulite-facies metamorphism during the Neoarchaean, followed by Palaeoproterozoic eclogite-facies metamorphism dated at c. 1.7 Ga (Storey et al. 2010). In contrast, the Eastern Glenelg gneiss contains abundant paragneisses in addition to orthogneisses. Paragneisses and other metasedimentary rocks include eclogite-facies kyanite-garnet bearing pelitic gneiss, graphitic pelite, forsterite marble and a variety of gneissose semipelitic to psammitic rocks (e.g. Storey 2008, and references therein). Eclogite is abundant and occurs as boudins or layers in both paragneisses and orthogneisses (Storey 2008). Eclogite-facies metamorphism and subsequent retrogression and exhumation occurred between 1080 and 995 Ma (Sanders et al. 1984; Brewer et al. 2003) during the Grenville Orogeny. No isotopic evidence of Grenvillian metamorphism has been found in the Western Glenelg gneiss. There is good evidence of an original (if deformed) unconformable relationship of the basal Morar Group onto the Western Glenelg gneiss, locally marked by a basal conglomerate (Clough, in Peach et al. 1910; Ramsay 1958; Barber 2009).

\section{Migmatitic Morar Group: the Morar Window}

In Knoydart and Morar, migmatitic metasedimentary rocks occur in the Morar Window, in the core of the Morar Antiform (Fig. 1b). These psammitic, semipelitic and pelitic rocks are highly recrystallized and deformed, commonly with coarse-grained gneissose, veined and migmatitic textures (Richey \& Kennedy 1939; Kennedy 1955; Lambert 1958; Lambert \& Poole 1964). Quartz and quartz-feldspar segregations with stromatic or augen textures are abundant; pegmatitic veins are also common. Sedimentary structures and younging evidence have been mostly obliterated. Deformation is pervasive and includes shearing and abundant small-scale folding. Although originally interpreted as an older, pre-Moine sequence (the 'SubMoine’ of Richey \& Kennedy 1939), it is now recognised that these rocks represent strongly modified Morar Group (Kennedy 1955; Lambert \& Poole 1964; Powell 1966). For the sake of brevity, these rocks are referred to here as "migmatitic Morar Group” in the remainder of this paper. 


\section{Previous structural interpretations}

The area has been studied previously by Ramsay \& Spring (1962) and Poole \& Spring (1974) who recognised three major deformation phases. A key feature is the Morar Window (Fig. 2) formed by the dome shaped (periclinal) Morar Antiform (e.g. Lambert \& Poole 1964), that exposes migmatitic Morar Group, surrounded by a thin sliver of basement gneiss. Structurally higher units broadly young upwards from the core of the Morar Antiform towards the west and east (Fig. 1b, 2). The Morar Antiform and Loch Hourn Antiform occur in en echelon arrangement; both have been assigned to a late-stage ' D3' deformation phase (Ramsay \& Spring, 1962; Poole \& Spring, 1974).

In eastern Knoydart, a major thrust termed the 'Knoydart Slide' has been interpreted along the contact between the Barrisdale Psammite and the Morar Pelite Formation (Poole \& Spring 1974; Powell 1974; Barr et al. 1986; Soper et al. 1998). Above this thrust, within the outcrop of the Morar Pelite Formation (= Ladhar Bheinn Pelite in east Knoydart, Figs. 3, 4), Poole \& Spring (1974) described the Knoydart Fold, interpreted as an inverted (synclinal) antiform, facing towards the east, and refolded by the later F3 Beinn Sgritheall Synform farther east (see also Powell 1974).

\section{Stratigraphy and lithology}

\section{Lewisianoid gneiss}

The basement gneiss inliers in Knoydart include an oval outcrop of gneiss slivers bounding the Morar Window, exposed on both sides of Loch Nevis (Fig. 1b), and a small inlier near Slisneach in NW Knoydart (Fig. 2). The inlier at Slisneach is made up of grey quartzo-feldspathic gneiss, with abundant amphibolite pods and layers, typically 10-40 cm thick (Fig. 4a). Parts of the gneiss are white and may represent tonalitic protoliths. Locally, deformed agmatitic textures occur; paragneiss is absent. The gneisses in SW Knoydart around the Morar Window are similar, but more strongly deformed and commonly intensely foliated. The lack of paragneiss and abundance of amphibolite pods, interpreted as deformed mafic dykes, implies that the gneisses are best assigned to the Western Glenelg gneiss.

\section{Morar Group}

The lower part of the Morar Group in Knoydart is dominated by the Lower Morar Psammite Formation, subdivided into a number of units as shown in Fig. 3 (Ramsay \& Spring 1962). The underlying Basal Pelite Formation occurs in places in contact with basement gneiss and comprises pelite and semipelite; it is typically highly strained with abundant quartz veins. Metaconglomerate as seen at the contact between the Morar Group and the Glenelg Inlier near Attadale (Clough, in Peach et al. 1910, Ramsay 1958, Barber 2009) has not been observed in Knoydart. The lowest unit of the Lower Morar Psammite Formation is the Arnisdale Psammite, which is typically buff to pink, thick-bedded (>1 m) but fine grained. 


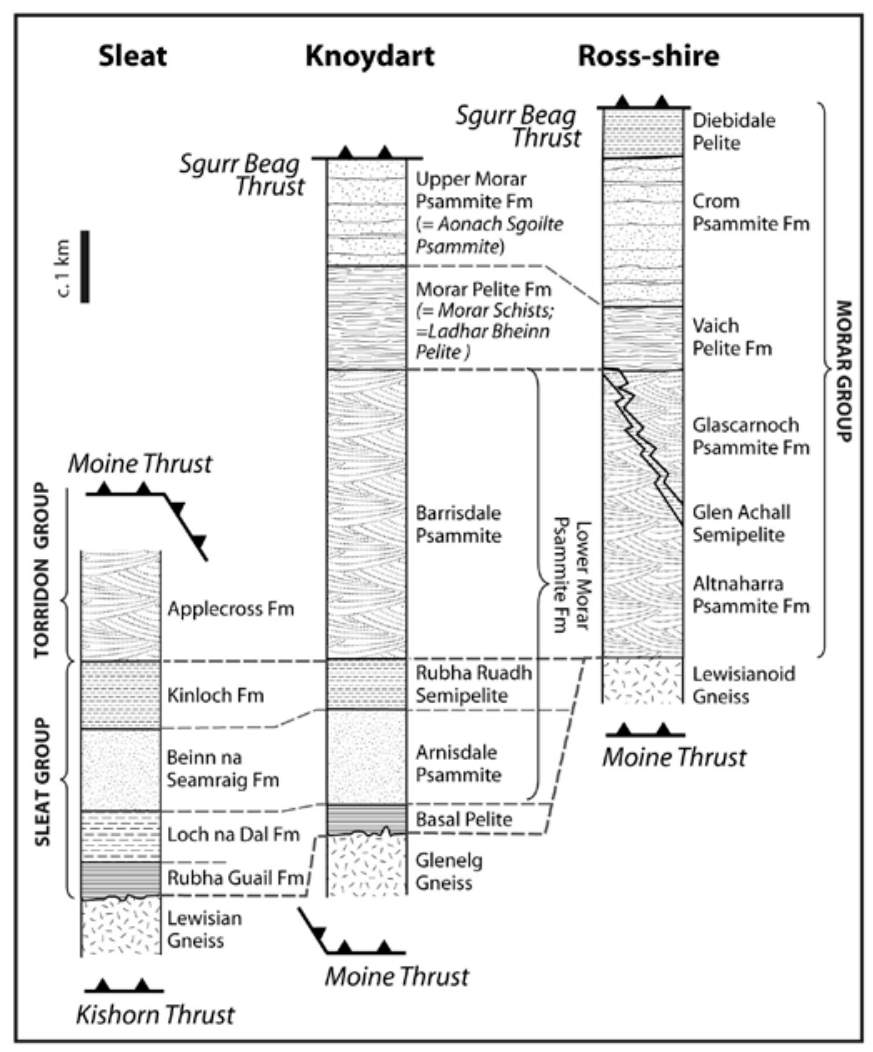

Fig. 3.Stratigraphy of the Morar Group in Knoydart (Ramsay \& Spring 1962; this study) and Ross-shire (Bonsor et al. 2012) and the Sleat Group on Skye (Sutton \& Watson 1964; Stewart, 2002), showing suggested correlations - further discussed in text.

Sedimentary structures are rare and ill-defined and any intrabed laminations are typically wispy (Fig. 4b). The Rubha Ruadh Semipelite consists of interlayered thinly bedded psammite, semipelite and pelite, with a general upward increase in pelitic material. Garnets are rare to absent and calc-silicate rocks are absent. Near Inverie Church (Fig. 2), a somewhat unusual quartz pebble conglomerate with a semipelitic matrix occurs within this unit (Fig. 4c). The lower boundary of the Rubha Ruadh Semipelite is transitional whereas its upper boundary with the Barrisdale Psammite is sharp (Ramsay \& Spring 1962). The Rubha Ruadh Semipelite is less continuous than originally described and appears to thin towards the south. As a result, in southern Knoydart the distinction between the Arnisdale and Barrisdale psammites is less clear. In Morar, the two psammite units have not been mapped separately (e.g. Poole \& Spring 1974).

The Barrisdale Psammite, the top unit of the Lower Morar Psammite Formation, is notably coarser than the Arnisdale Psammite; bed thickness varies from 50-400 cm. In low strain zones, particularly east of the Loch Hourn Antiform, sedimentary structures are obvious and abundant, commonly delineated by heavy mineral bands. These include channels with stacked planar and trough cross-bedding in cosets typically 30 $100 \mathrm{~cm}$ thick (Fig. 4d, e). Soft-sediment deformation structures are abundant (Fig. 4f); in places completely fluidised beds up to $4 \mathrm{~m}$ thick occur. Although no systematic analysis has been carried out, the Barrisdale Psammite shows similar sedimentary structures to the braided river facies in the Altnaharra Psammite 

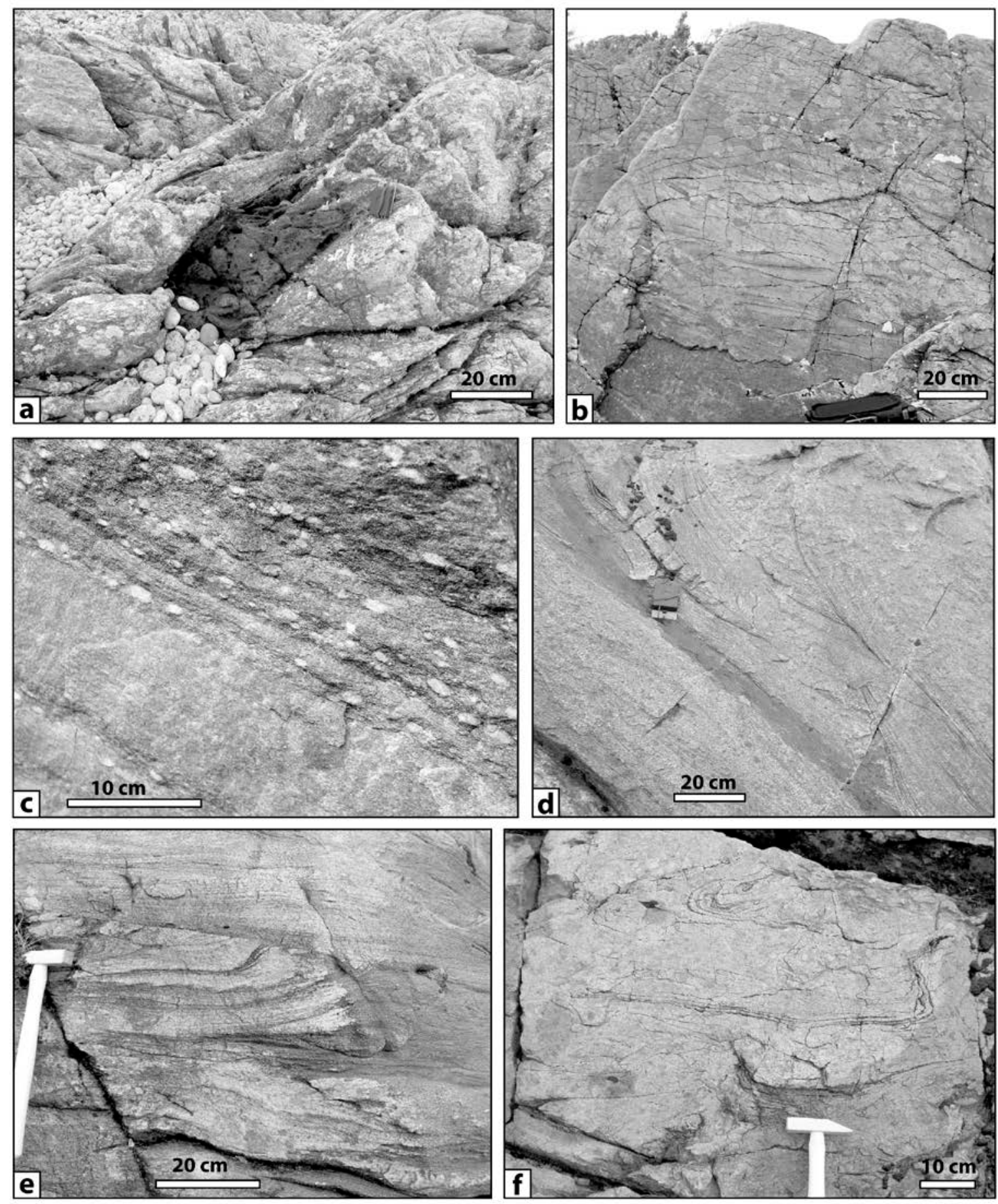

Fig. 4. Photos of lithologies.

(a) Amphibolite pod in tonalitic gneiss. Rubha Ard Slisneach, [NG 7479 0901], BGS Photo P877787.

(b) Fine-grained buff psammite, thick-bedded with wispy sedimentary laminae. Arnisdale Psammite. Aultvoulins, [NG 7593 0039], BGS Photo P883641.

(c) Semipelite and micaceous psammite with flattened quartz pebbles. Probable Rubha Ruadh Semipelite. Inverie Church, [NM 7678 9993], BGS Photo P883650.

(d) Coarse-grained siliceous psammite with well-defined trough cross-bedding, younging to east; Barrisdale Psammite. $1 \mathrm{~km}$ SW of Beinn na Cailich, [NG 7885 0581], BGS Photo P877809.

(e) Coarse psammite with heavy mineral bands and oversteepened and truncated cross-bedding.. Barrisdale Psammite. Mam Li. [NG 8040 0580], BGS Photo P779591.

(f) Siliceous psammite with internal crossbeds and soft-sediment deformation ('slump folding'). Barrisdale Psammite. Mullach Li. [NG 8125 0658], BGS Photo P7796049. 
Formation in Sutherland (Krabbendam et al. 2008) and the Applecross Formation (Torridon Group) in the Caledonian Foreland (Nicholson 1993; Stewart 2002). The Barrisdale Psammite becomes more thinly bedded and finer grained upwards, with an increase in semipelitic beds towards its upper contact with the Morar Pelite. Nevertheless, the contact with the Morar Pelite is fairly sharp.

The Morar Pelite Formation consists of massive garnetiferous semipelite with locally abundant layers or pods of calc-silicate rock, as well as sequences of interbedded semipelite and psammite. The latter are well exposed in steeply dipping strata near Airor, in western Knoydart (Fig. 2). The Upper Morar Psammite only occurs at high structural levels in eastern Knoydart, where it has been termed the Aonoch Sgoilte Psammite (Ramsay \& Spring 1962), but this was not visited during this study.

\section{Sleat Group}

The Sleat Group crops out on the Isle of Skye, close to Knoydart but west of the Moine Thrust (Fig. 1b). The group only occurs in the Kishorn nappe, where it is folded in the kilometre-scale west-facing, recumbent Lochalsh Syncline and subjected to very low greenschist-facies metamorphism. The group comprises some $3500 \mathrm{~m}$ of Neoproterozoic siliciclastic sedimentary rocks (Fig. 3), divided into four formations (e.g. Peach et al. 1910; Stewart 2002). The lowermost Rubha Guail Formation is dominated by coarse-grained sandstone with minor laminated siltstone. Conglomerate, typically strongly deformed, occurs locally in contact with Lewisian basement gneiss. The overlying Loch na Dal Formation comprises laminated mudstone, siltstone and sandstone. The Beann na Seamraig Formation is dominated by sandstone. Stewart (2002) presented a log from Glen Arroch in Skye showing coarse-grained sandstone with abundant, well defined trough crossbedding and channels. This facies, however, is atypical for the formation. Instead, most of the Beann na Seamraig Formation on Skye and Lochalsh consists of buff, fine-grained sandstone, with thick (up to $4 \mathrm{~m}$ ) almost structureless beds with very poorly defined sedimentary structures and very diffuse laminations. The highest Kinloch Formation comprises fine-grained sandstone and shale, commonly with well-preserved ripplelaminations. The Sleat Group is overlain by the Applecross Formation (Torridon Group), separated by a lowangle unconformity (Kinnaird et al. 2007).

\section{Deformation phases, fabrics and folds}

The Moine Nappe has been affected by several distinct deformation phases, locally showing clear overprinting relationships. The deformation sequence used herein, and detailed below, is consistent with that of Ramsay (1960, 2010), Ramsay \& Spring (1962) and Powell (1966, 1974), but not necessarily with that in other publications.

- D1 comprises isoclinal folds of variable scales that are refolded by D2 folds and/or overprinted by D2 fabrics. These folds are often only recognisable by careful mapping and recognition of repetition within the sequence, or by clear overprinting by D2 structures. In low strain zones no obvious S1 
fabric has been detected in psammite. D1 strain appears strongest at structurally low levels, especially close to the gneiss sliver in SW Knoydart (Fig. 5a), where it defines a diffuse shear zone. In highly strained psammite, platy layering may well comprise bedding and a transposed S1 fabric (Fig. 5b).

- D2 is characterised by a penetrative fabric (S2) and is broadly peak-metamorphic (Tanner 1976, Powell 1974). In psammite, S2 is typically a quartz-flattening fabric and consistent alignment of dispersed biotite (Fig. 5c to 5f). In more pelitic rocks, S2 is commonly a penetrative schistosity defined by micas and quartz. In these rocks it is possible that observed S2 is in fact a composite S1 + S2 fabric. Alternatively, S2 in pelitic rocks in low-strain zones can be a spaced crenulation cleavage (Fig. 5d). Observed L2 lineations are typically intersection lineations between bedding and S2; L2 mineral lineations or rodding occur only rarely. D2 strain was moderate over much of the area, as indicated by the absence of strong L2 rodding and the generally high angles between bedding and S2 (Figs. 5d, e, f). Fold styles depend on the amount of strain and lithology and range from open-toclose, near-concentric folds in thick-bedded psammite, to tight, similar folds in thinly layered, more pelitic lithologies.

- D3 folds demonstrably crenulate or fold the S2 fabric, and thus clearly post-date D2. Only minor recrystallisation occurred during D3; new fabrics are restricted to the hinge zones, and are a crenulation cleavages, deforming older fabrics. F3 folds are typically open to close; no tight or isoclinal F3 folds have been identified; in finely foliated rocks kink folds may occur (Fig. 6). All deformation phases produced folds ranging from centimetre to kilometre scale. They all involve Morar Group rocks and hence post-date Morar Group deposition. We stress that this particular deformation phase scheme is only valid within the southern Moine Nappe. Deformation phases in the Moine outcrop cannot be correlated a priori across major thrusts (Leslie et al. 2010; Krabbendam et al. 2011). For instance, the peak of metamorphism that accompanied D2 as defined here in the Moine Nappe is most likely not coeval with peakmetamorphic structures in the Sgurr Beag Nappe, which are also typically termed 'D2' (Powell 1974; Tanner 1971; Mendum 2009). Indeed, there is a geochronological evidence which suggests that 'D2' in the northern Moine Nappe in Sutherland formed during the Scandian event (e.g. Kinny et al. 2003; Thigpen et al. 2013, but see Bird et al. 2013); whilst 'D2’ in the Sgurr Beag Nappe relates to the Grampian event (Cutts et al. 2010).

\section{Structure and overall geometry}

The basic structure of Knoydart is a series of kilometre-scale, north-trending F2 and F3 folds that deform an earlier, isoclinal F1 fold nappe cored by basement gneiss (Ramsay \& Spring 1962; Poole \& Spring 1974; Powell 1974). 

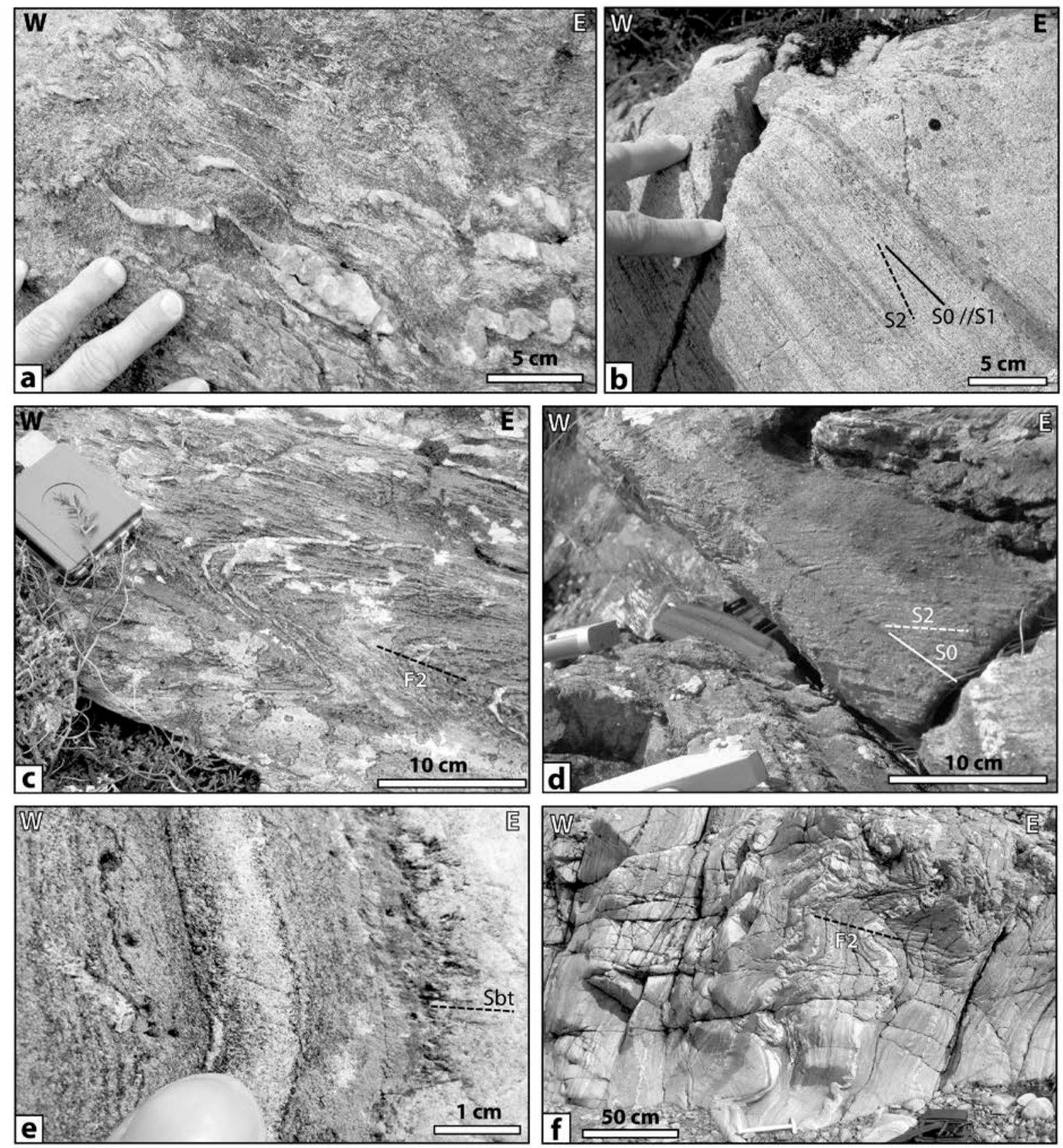

Fig. 5. Photos of structures (D1 and D2)

(a) Sheared Basal Pelite with abundant deformed quartz veins; intense fabric probably superimposed S1 and S2; minor westvergent folds of probable D2 age. 1 km east of Sandaig, [NG 7306 0193], BGS Photo P883630.

(b) Highly strained, platy psammite layers in Arnisdale Psammite close to Basal Pelite; east of Morar Antiform. S2 fabric makes small angle (indicating westerly vergence) to platy layering (bedding and probable transposed S1). $1 \mathrm{~km}$ north of Glaschoille House, [NG 7380 0106], BGS Photo P883634.

(c) Tight, west-vergent vergent F2 folds in eastern limb of Loch Hourn Antiform, Rubha Ruadh Semipelite. SW slopes of Creag Dubh, [NG 7713 0462], BGS Photo P877832

(d) East vergent S0/S2 relationship in overturned limb of minor fold in hinge zone of F2 Airor Antiform. Garnetiferous pelite, with layers of semipelite and micaceous psammite, Morar Pelite Formation. View to SSW. Airor Harbour, [NG 7172 0535], BGS Photo P779615.

(e) Interbedded pelite, semipelite, psammite (Morar Pelite), with biotite (Sbt) fabric at high angles to steep bedding, indicating near-neutral F2 vergence and presence of F2 fold hinge (Airor Antiform). $700 \mathrm{~m} \mathrm{NE}$ of Airor, [NG 7222 0598], BGS Photo P779623.

(f) Interbedded pelite, semipelite, psammite (Morar Pelite), with recumbent metre-scale F2 folds with near-neutral vergence. Hinge zone of Airor Antiform. 700 m NE of Airor, [NG 7222 0598], BGS Photo P779625. 

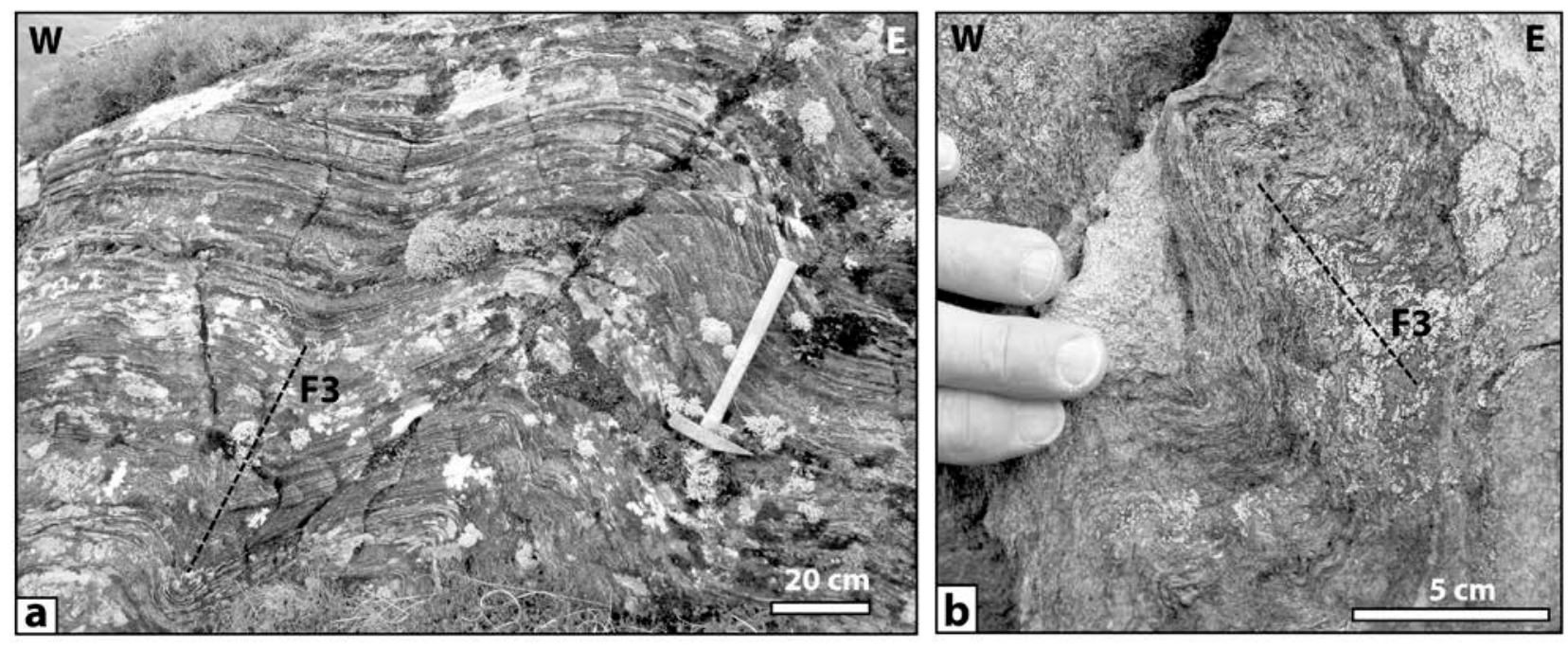

Fig. 6. Photos of D3 structures

(a) Open, upright folds (F3), eastern limb of Loch Hourn Antiform, Rubha Ruadh Semipelite. SW slopes of Creag Dubhg, [NG 7731 0441], BGS Photo P877835

(b) Intensely foliated gneiss, fabric crenulated by east-verging F3 folds; west limb of F3 Morar Antiform. 800 m ENE of Sandaig, [NG 7272 0222], BGS Photo P883625.

\section{Gneiss inliers and F1 folds}

In the Morar Window (Fig. 2, 7) basement gneiss is structurally underlain by migmatitic Morar Group semipelite and psammite, now exposed in the core of the Morar Antiform (Richey \& Kennedy 1939; Kennedy 1955; Lambert 1958). The occurrence of gneiss slivers bounded above and below by Morar Group rocks has been variously attributed to ‘sliding', or thrusting (e.g. Kennedy 1955), or to isoclinal folding (Lambert \& Poole 1964; Ramsay \& Spring 1962; Powell 1974). This may well be a somewhat moot point, as recumbent fold nappes with isoclinal cores commonly have highly sheared and attenuated limbs; a combination of isoclinal folding and shearing is thus likely (see also Poole \& Spring 1974).

Near Slisneach, gneiss occurs as a c. 50 m thick sliver with Morar Group psammites structurally below and above. The contact is parallel to bedding in the psammites, but locally makes a small angle with the gneissic layering. However, strain does not increase particularly towards the gneiss-psammite boundary, and the inverted contact with the underlying Morar Group psammite is interpreted as a deformed unconformity. This suggests that the Slisneach gneiss sliver forms the core of an isoclinal anticline. By analogy with the folds of Arnisdale (Ramsay 1960, 1963, 2010), this isocline is assigned to F1. The Slisneach gneiss sliver and adjacent psammites are folded by west-vergent F2 folds, and overall occurs within an F2 antiform, which to the east is followed by a synform and succeeded in turn by the Loch Hourn Antiform (Section A-A' - Fig. 7). A splay of the Strathconon Fault has brought up the Slisneach area up with respect to the rest of Knoydart. This implies that the Slisneach gneiss occurs structurally below the bulk of the Morar Group of Knoydart, at the same structural level as (and possibly connected to) the gneiss exposed in the Morar Window (e.g. Richey \& Kennedy 1939). 
In SW Knoydart, deformation close to the gneiss contact appears more intense. Pelite close to the contact has an intense schistosity with abundant strung-out quartz veins (Fig. 5a), whilst psammite has an intense proto-mylonitic fabric with transposed bedding and S1 fabrics, giving it a distinct 'tramline' appearance (Fig. 5b). The basement gneiss/Morar Group contact in SW Knoydart thus appears to be more strongly sheared than at Slisneach.

Inliers of migmatitic Morar Group and/or basement gneiss occur in the Morar Window, at Slisneach and farther north across Loch Hourn, all at the same structural level; it thus appears that basement gneiss with 'inverted’ migmatitic Moine underlies most of Knoydart and Morar. This suggests the presence of a major recumbent, isoclinal F1 fold cored by gneiss and with an intensely strained, migmatitic lower limb (Fig. 7); similar to interpretations of Lambert \& Poole (1964) and Powell (1974).

\section{F2 peak-metamorphic structures and transport direction}

The main penetrative fabric throughout Knoydart is S2 which is variably developed depending on lithology, but consistently defined by biotite. In northern and central Knoydart this S2 mica fabric dips consistently gently $\left(20-40^{\circ}\right)$ east, with a mean orientation of 084/34E (Fig. 8a), showing that the effects of F3 folding are limited in these areas. F2 fold axes and L2 intersection lineations generally plunge gently to the north or south (Figs. 2, 8a). These folds give no direct indication of transport direction. However, a broadly western or WNW transport direction is indicated by: i) the overall west-vergent and west-facing nature of the F2 folds; ii) a unimodal distribution of facing direction of F2 minor folds towards the west (Fig. 8b), suggesting broadly westward buckle folding, rather than development of sheath folds (compare with Holdsworth (1988) and Alsop \& Holdsworth (1993) for bimodal distribution at higher strain sheath folds); iii) rare ESE plunging stretching lineations in Knoydart (Fig. 8a); iv) more common ESE plunging stretching lineations in F2 high strain zones in neighbouring Glenelg area (Ramsay 1963). Minor F2 folds axes do show a spread towards both the SE or NE, suggesting a limited amount of rotation towards the transport direction. Note: throughout this paper, facing is used to mean fold facing, that is the younging direction within the axial plane of a fold. 


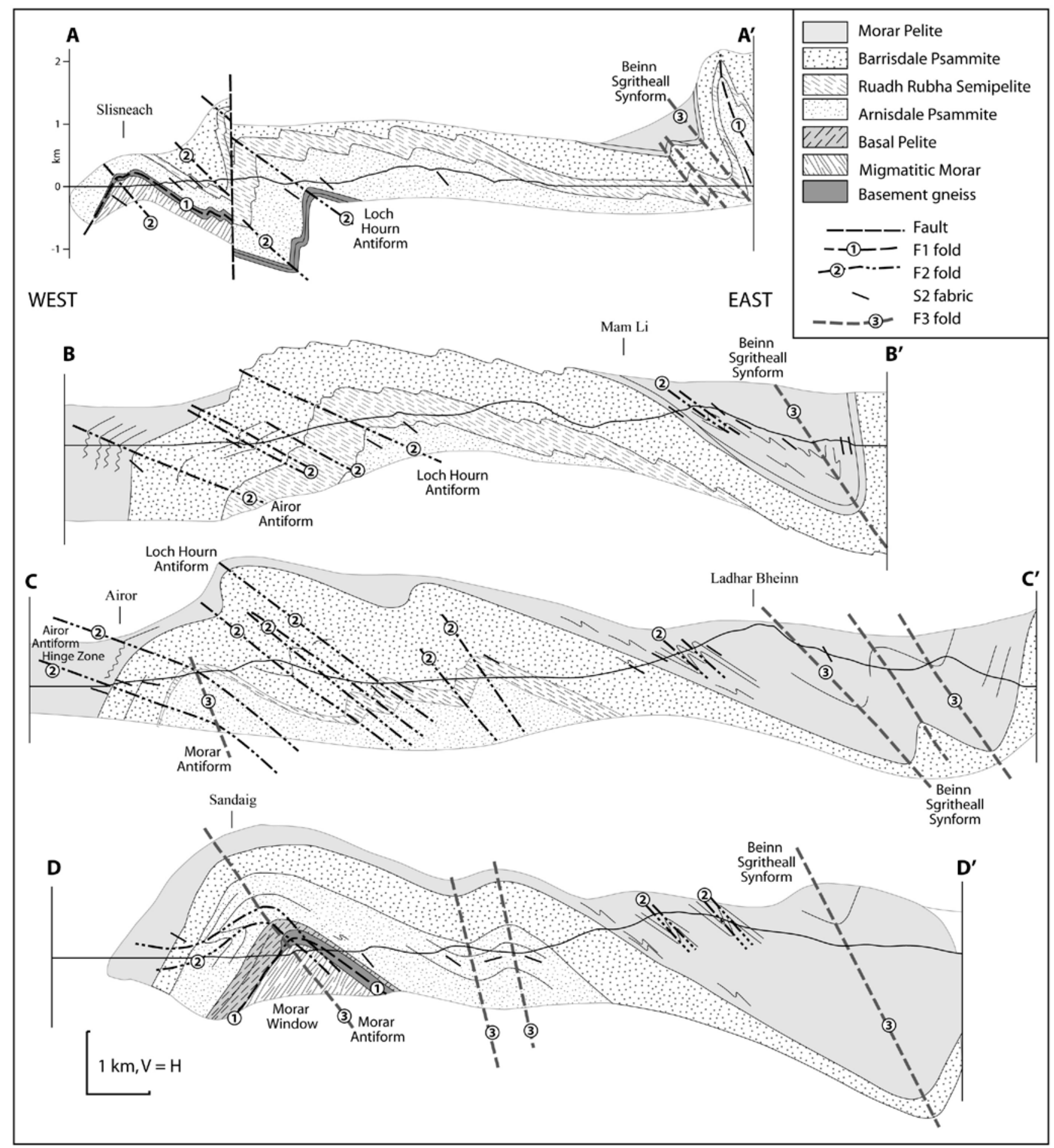

Fig. 7. Cross-sections through Knoydart. Lines of section shown in Figure 2. 


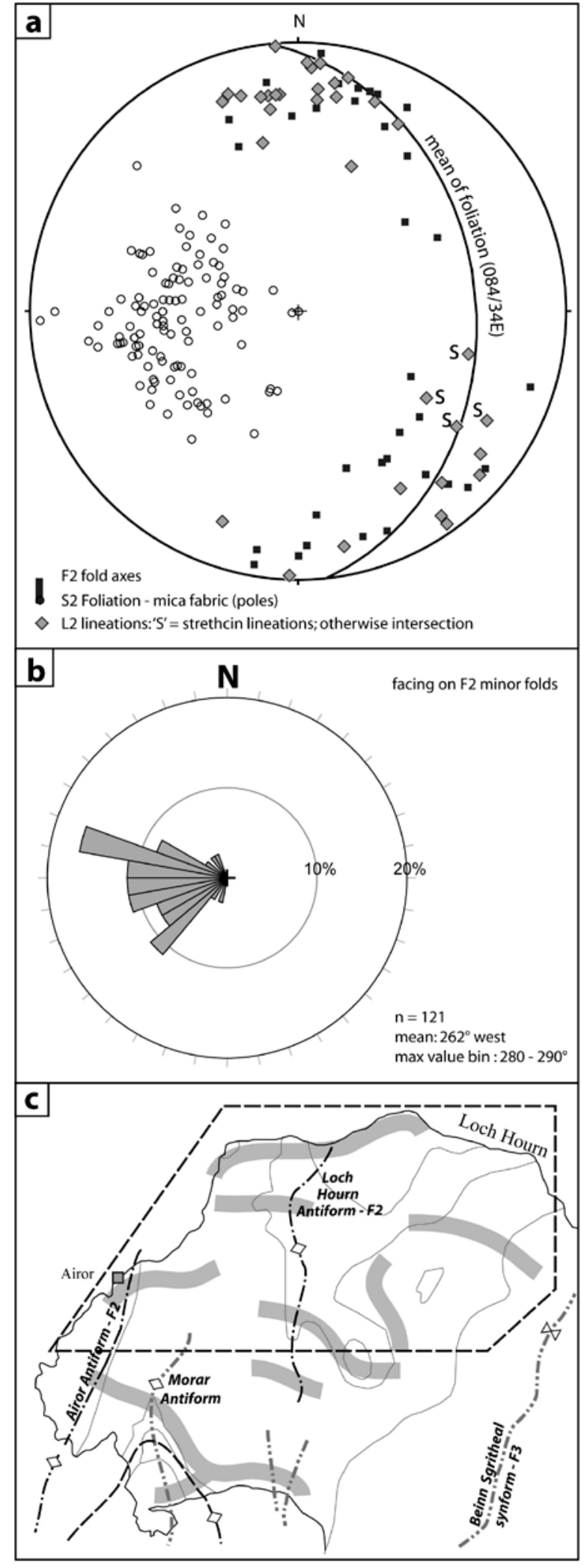

Fig. 8. (a) Stereograms of structural data of D2 structures in northern and central Knoydart (see box in (c)). S2 foliation plotted as poles, except for mean, which is plotted as a great circle. Equal area lower hemisphere projection.

(b) Rose diagram of facing direction on F2 folds (cf. Holdsworth 1988)

(c) Map showing area of structural data plotted in (a) (box); note that this box excludes F3 folds. Transects mapped for this study indicated in grey. 


\section{Loch Hourn Antiform}

The large-scale Loch Hourn Antiform (Fig. 2) is an asymmetric fold, with a long limb dipping 20-40 to the east, and a shorter steep, vertical to overturned limb in the west (Sections A-A' to C-C' on Fig. 7). Its axial plane dips c. $30^{\circ}$ to the east (Fig.7, 8). S2 fabrics consistently dip to the east on both limbs, parallel to the axial plane; vergence of bedding/S2 and parasitic folds clearly changes from one limb to the other. S2 is axial planar to the Loch Hourn Antiform, which is thus patently an F2 fold (cf. Poole \& Spring 1974). West of the Loch Hourn Antiform are a number of parasitic, 100 m-scale F2 synforms and antiforms, typically with gentle east-dipping limbs alternating with steep to overturned limbs, all with easterly dipping axial planar biotite fabrics. The overall pattern is thus a series of F2 folds that verge and (given the local right-way-up sequence) face towards the west (Fig. 7). The recumbent nature of the F2 folds means that antiformal hinge zones are positioned west of the crest lines (Fig. 7).

\section{'Knoydart Slide' and 'Knoydart Fold'}

In eastern Knoydart, a high strain zone along the Barrisdale Psammite - Morar Pelite contact has been thought to represent a 'Knoydart Slide', a thrust of regional importance at the base of the 'Knoydart nappe’ (e.g. Poole \& Spring 1974; Powell 1974; Barr et al. 1986; Mendum 2009). Just east of this purported thrust, a major F2 antiform (the 'Knoydart antiform' or 'Knoydart Fold') has been proposed within the outcrop of the Morar Pelite Formation. This fold would face downward to the east (Poole \& Spring 1974; Powell 1974) and be refolded by the later F3 Beinn Sgritheall Synform near Ladhar Bheinn to reappear farther east and fold the outcrop of the Anoch Sgoilte Psammite. The trace of the 'Knoydart fold' was interpreted rather differently by Poole \& Spring (1974) and Powell (1974), probably reflecting poor control of its trace within the large outcrop of monotonous Morar Pelite around Ladhar Bheinn.

A major problem with the existence of an east-facing F2 fold is that the vast majority of major F2 (and F3) structures elsewhere in the Moine Nappe face upwards to the west (e.g. Holdsworth 1988; Strachan \& Holdsworth 1988; Alsop et al. 2010; Leslie et al. 2010; Krabbendam et al. 2008; 2011), so an east-facing fold would be highly unusual.

The existence of the 'Knoydart Fold' and 'Knoydart Slide' was tested by mapping along a 3 km long transect eastward from Mam Li (Fig. 2; Section B-B' on Fig. 7). The following features, described from west to east, were recorded. The middle part of the Barrisdale Psammite contains abundant, well-preserved rightway-up sedimentary structures (e.g. soft sediment deformation structures, trough cross-bedding, laminations, Fig. 4d, e, f). The psammites at this level show no evidence of strain or fabric development. In the upper part of the Barrisdale Psammite, interbedded semipelitic beds contain a biotite fabric (S2) that dips more steeply east than bedding, indicating westerly vergence, consistent with their position on the eastern limb of the F2 Loch Hourn Antiform. Strain increases upwards towards the contact with the Morar Pelite Formation, with the rocks becoming increasingly flaggy. In the Morar Pelite Formation, the mica fabric becomes intense, resulting 
in a completely superposed S0/S2 foliation, in which vergence cannot be determined. However, bedding can recognised in more competent calc-silicate layers. Tight, small-scale folding (with axial planar mica fabric = S2) of these calc-silicate layers shows several vergence reversals, but westerly vergent folds remain dominant over easterly vergent folds. This sequence is interpreted as an overall west-vergent stack of tight, small-tomedium scale F2 folds. The evidence of consistent overall westerly vergence refutes a single east-facing Knoydart antiform. There is no evidence for an east-facing F2 antiform west of the Beinn Sgritheall Synform.

The combination of high strain and overall westerly vergent F2 folds is maintained throughout the lower c.800 m of the Morar Pelite outcrop. The Morar Pelite in eastern Knoydart is thus pervasively sheared and folded by non-coaxial deformation over a significant thickness and represents deformation internal to a nappe without disrupting the overall stratigraphical order, rather than defining a distinct 'Knoydart slide' that bounds a nappe.

\section{Major F3 folds}

Near Inverie an open, upright antiform-synform pair deforms both bedding and S2 fabrics (Fig. 2) and is assigned to D3. Farther north, near Creag Dubh in central Knoydart, minor upright F3 folds deform bedding and S2, but have no appreciable axial planar fabric (Fig. 6a).

The Beinn Sgritheall Synform (formerly Ben Sgriol Synform, e.g. Ramsay 1960) farther east folds a wide swath of Morar Pelite (Fig. 1b, 2), not mapped in detail. The hinge of the Beinn Sgritheall Synform is well exposed south of Arnisdale, where all penetrative fabrics (S1 and S2) are folded around the hinge zone, within which only an axial planar crenulation cleavage is developed; the fold is therefore attributed to F3 (Ramsay 1960, 2010). This F3 synform trends north-south and has a very long (> $20 \mathrm{~km}$ ) and consistently east dipping axial plane that can be traced from Loch Hourn to Loch Morar (Fig. 1b). Its western limb dips gently east and in essence comprises most of the Knoydart Peninsula; its eastern limb is subvertical to overturned (Ramsay 1960). In Knoydart, the trace of the Beinn Sgritheall Synform lies mostly in Morar Pelite. Together with F2 folds and subsidiary F3 folds, it has thickened the outcrop of the Morar Pelite considerably (e.g. Poole \& Spring 1974). South of Loch Nevis, the Beinn Sgritheall Synform loses amplitude and its role is taken over by the Glenshian Synform (Fig. 1b), which folds the Sgurr Beag Thrust (Powell 1974; Mendum 2009). Farther east and southward, F3 folding becomes more pronounced and more abundant into the regionally significant 'Northern Highland Steep belt' (e.g. Roberts \& Harris 1983; Roberts et al. 1987)

\section{F2-F3 overprinting: the F2 Airor Antiform and F2/F3 Morar Antiform}

In western Knoydart and Morar, bedding in the Morar Pelite dips steeply west and youngs towards the west (Fig. 2, 5). This attitude is traditionally attributed to the regional scale, periclinal F3 Morar Antiform, whose plunge culmination is responsible for the oval outcrop shape of the Morar Window (e.g. Richey \& Kennedy 
1939; Ramsay \& Spring 1962; Poole \& Spring 1974). However, near Airor in west Knoydart, the S2 biotite fabrics in both the Morar Pelite and upper part of the Barrisdale Psammite retain gentle (c.10-20 $)$ easterly dips (Fig. 2, 8). Recumbent, neutrally vergent folds with an axial planar biotite S2 fabric, and high angles between steeply-dipping bedding and shallow-dipping S2 (Fig. 5d, e, f), indicate the presence of a recumbent F2 hinge zone, which faces to the west (Fig. 7). Fold axes and L2/0 intersection lineations plunge gently $\left(<20^{\circ}\right)$ to the north. The hinge zone is several kilometres wide, and many hundreds of metres thick. No minor F3 folds have been recognised near Airor and, as the S2 fabric dips gently eat throughout (Fig. 2, 8a), major F3 folds can be discounted. The steeply dipping strata of the Morar Group in NW Knoydart thus form the steep limb of a major recumbent, west-facing F2 fold, here termed the Airor Antiform (Fig. 2, 5). The steep dip of bedding in west Knoydart is therefore primarily attributed to F2 folding.

In SW Knoydart, however, the situation is more complicated. Here, between Sandaig and Scottas (Fig. 2), the northward plunging Morar Antiform is responsible for the 'hook-shaped' outcrop of basement gneiss with migmatitic Morar Group below. A transect through this antiform showed that psammite close to the contact near Scottas is highly strained, with transposed S0/S1, attesting to high D1 strain associated with an isoclinal F1 fold, cored by basement gneiss (see also Lambert \& Poole 1964). S2 dips east, but slightly steeper than bedding, indicating westerly vergence on S2 (Fig. 5b). Just west of the hinge of the Morar Antiform, close, upright kink-like folds with easterly vergence deform intensely foliated gneiss (Fig. 6b). These minor folds have an axial planar crenulation fabric and are assigned to F3, consistent with their position just west of the Morar Antiform hinge. North of Sandaig, both bedding and S2 are steep and S0/S2 relations show both westerly and easterly vergence (Fig. 2). At least one high strain zone was seen. The full interpretation of this area remains elusive due to restricted exposure, but one possible explanation is that there are a series of tight F2 folds, here refolded by the F3 Morar Antiform such that they are now downward facing (section D-D', Fig. 7). These subsidiary F2 folds can be regarded to be part of the wide hinge zone of the F2 Airor Antiform. This suggests that the Morar Antiform (sensu lato) is not solely an F3 feature; rather it initially formed as a major recumbent F2 antiform (Airor Antiform), subsequently tightened and partially refolded by a more upright F3 Morar Antiform.

Throughout Knoydart, F3 folding is only significant near the south coast, and farther east in the hinge zone of the F3 Beinn Sgritheall Synform (Fig. 2, 5). Central and northern Knoydart were barely affected by D3 deformation. F2 and F3 folds are broadly coaxial, but not coplanar; F2 axial planes initially dipped gently east whereas F3 axial planes dip more steeply to the east (Fig. 7). The relative intensity of F2 vs. F3 folding in the Morar Antiform farther south in Morar has not been investigated in this study. 


\section{Discussion}

The geological structure of Knoydart is dominated by an internally coherent, right-way-up sequence of Morar Group rocks, several kilometres thick (Fig. 2, 5). This sequence has been deformed by large-scale, westvergent and west-facing F2 folds (e.g. Loch Hourn Antiform, Airor Antiform and associated synforms) that trend north-south. The medium-strain nature of the folds, the unimodal distribution of facing orientations to the west, and the mineral stretching lineations in adjacent high strain zones all suggest a regional westerly transport direction. Some folds have been tightened further by F3, so that the Morar Antiform is a composite F2/F3 fold. There is no east-facing 'Knoydart Fold'; instead all folds face towards the west.

Poole \& Spring (1974) used thickness variations of calc-silicate bearing parts of the Morar Pelite between east and west Knoydart as evidence for a 'Knoydart Slide'. However, such thickness variations can also be explained by variable amounts of thickening by folding, or by original stratigraphic facies changes. Barr et al. (1986) suggested that the Knoydart Slide was marked by a jump in metamorphic grade from relatively low-grade in the east (c. $500 \pm 30 \mathrm{C}^{\circ}$ ) to higher grade $\left(580 \pm 30 \mathrm{C}^{\circ}\right)$ in the Morar Pelite. However, data points are sparse and it is unclear whether this represent a real jump or a more gradual change. The 'Knoydart Slide’ coincides with a stratigraphic boundary separating rocks of different composition (siliceous psammite vs. micaceous and locally calcareous pelite), which respond rather differently to elevated pressure and temperature and imposed deformation. Thus, whilst it is clear that there is a broad eastward increase in metamorphic conditions, there is no unequivocal evidence for a sharp step across a putative 'Knoydart Slide'. Thygpen et al. (2013) presented a model that explains a broad increase in metamorphic grade developed in the overall west-vergent fold-and-thrust belt in the Moine rocks of Sutherland and Ross-shire. In this area, a number of high strain zones occur within the Moine Nappe sensu lato (e.g. Achiniver, Ben Hope and Achness thrusts, Holdsworth et al. 2007; Alsop et al. 2010; Leslie et al. 2010). These thrusts invariably have slivers of basement gneiss in their hangingwalls, clearly duplicate the stratigraphy and have significant displacements. They are thus very different from the small localised high strain zone along the Barrisdale Psammite / Morar Pelite contact described above.

We conclude that the high strain rocks near the 'Knoydart Slide' are best explained by a pronounced competence contrast between competent Barrisdale Psammite and incompetent Morar Pelite and the resulting response to F2 deformation internal to the Moine Nappe. This differential strain is particularly marked in the long, gentle east-dipping limbs of regional F2 folds; the steep west-dipping strata in hinge zone of the F2 Airor Antiform shows no evidence of notably high strain (Fig. 5f). The stratigraphic units patently follow each other in normal order; there is neither disruption nor repetition of the stratigraphic order (cf. Barr et al. 1986). We conclude that this high strain zone has no regional significance and there is no separate 'Knoydart Nappe' (cf. Poole \& Spring 1974; Powell 1974; Barr et al. 1986).

The whole package of west-facing and west-vergent F2 and F3 folds overlies an isoclinal F1 fold 
which probably underlies much of Morar and Knoydart (see also Powell 1974). The core of the isoclinal F1 fold is marked by a thin sliver of Lewisianoid basement gneiss, whilst the lower limb comprises intensely deformed and migmatitic Morar Group rocks, forming the lowest structural levels. The core and lower limb of this fold nappe are exposed in the Morar Window and near Slisneach, brought to higher levels by F2 and F3 antiforms. In Knoydart there is no evidence as to the facing and/or transport direction of the D1 nappe.

\section{Timing of events}

As described above, several orogenic episodes have affected the Moine sequence in the Northern Highlands, ranging from Mid-Neoproterozoic to Silurian in age, but it remains unclear which structures were formed during which orogenic event (e.g. Tanner \& Bluck 1999). Some studies have implicitly assumed a single D1Dn sequence for the entire Moine outcrop; however geochronological studies now suggest up to seven orogenic events: three during the Palaeozoic, and two to four during the Neoproterozoic (e.g. Bird et al. 2013; Cawood et al. in press). The number of dated events now exceeds the number of deformation phases in any one place. It is clearly necessary to (re-)analyse which deformation phase in which area can be linked to which orogenic phase.

In the southern Moine Nappe, Knoydartian activity is indicated by Rb-Sr mineral and U-Pb zircon ages from pegmatites (e.g. van Breemen et al. 1974; Powell et al. 1983; Rogers et al. 1998), U-Pb titanite ages from below the Sgurr Beag Thrust (Tanner \& Evans 2003), and Sm-Nd ages from garnet (Vance et al. 1998) see Figure 1 for some localities. These ages fall into two clusters: c. 830-800 Ma and 780-740 Ma. It has been suggested that Knoydartian tectonothermal events were related to an extensional event (Dalziel and Soper 2001). However, studies on garnet have linked Knoydartian ages with metamorphic P-T conditions consistent with crustal thickening and orogenesis (Vance et al. 1998; Cutts et al. 2009, 2010). It is likely that Knoydartian garnet growth as well as pegmatite intrusion were broadly associated with isoclinal D1 folding in Morar Group rocks and we concur with the concept that D1 isoclinal folds were formed during a Knoydartian orogeny (see also Vance et al. 1998; Rogers et al. 1998). However, the exact timing and nature of events remains problematic as the Knoydartian ages appear to cluster in (at least) two phases (see Cutts et al. 2010).

It has been proposed that D2 in the southern Moine Nappe is also of Knoydartian age, but unequivocal evidence for this is lacking (see discussion in Rogers et al. 1998). The structural relationships of individual dated pegmatites have been disputed: e.g. for the c. 827 Ma pegmatite at Ardnish, Powell et al. (1983) suggested a post-D2/pre-D3 age whereas Rogers et al. (1998) assigned a post-D1/pre-D2 age, which is more likely.

Storey et al. (2004) reported a $437 \pm 6 \mathrm{Ma}$ U-Pb titanite age from a 'post-D2' pegmatite within the Eastern Glenelg gneiss. Bird et al. (2014) reported garnet Lu-Hf and Sm-Nd ages ranging between 466 and $447 \mathrm{Ma}$ in the southern and northern Moine Nappe, most likely dating peak-metamorphic conditions, generally attributed to D2. Cawood et al. (in press) report a $446 \pm 2 \mathrm{Ma}$ U-Pb zircon age for a 'syn-D2' pegmatite on the 
north shore of Loch Hourn. The bulk of this geochronological evidence suggests that D2 in the southern Moine Nappe is Caledonian (sensu lato), but occurred between 460 and $440 \mathrm{Ma}$, between the archetypal 'Scandian' and 'Grampian’ phases. Most ages are rather older than the typical 'Scandian' (440 - $420 \mathrm{Ma})$ ages reported for peak-metamorphic deformation ('D2') and pegmatite intrusions in the northern Moine Nappe (Kinny et al. 2003; Kocks et al. 2006; Alsop et al. 2010; Goodenough et al. 2011). Within the Moine Nappe, 'D2' thus appear to be diachronous: whether this is because of a distinctly separate late-Ordovician 'Grampian II' event (e.g. Bird et al. 2013) or a more protracted Grampian-to-Scandian progressive event is difficult to tell. If further geochronological analyses confirm the existence of a late-Ordovician 'Grampian II' in the southern Moine Nappe, distinct from the Silurian 'Scandian' events in the northern Moine Nappe, some sort of lateral ramp may have operated between these two areas. If so, this lateral ramp may have been the Oykel Tranverse Zone, which separates a higher Achness Thrust Nappe, from lower (and younger) thrust sheets to the north (Leslie et al. 2010).

During D3, micas are deformed (crenulated), rather than growing along axial planes, and the fold geometry shows that D3 operated in a similar overall strain regime as D2, except under cooler conditions (see also Thigpen et al. 2013). On a large-scale, the geometry and kinematics of D2 and D3 deformation in Knoydart are very similar to those established in the Moine Nappe in Ross-shire (Krabbendam et al. 2011); in both areas D2 and D3 relate to overall non-coaxial deformation, resulting in major folds that verge and face towards the west, consistent with overall WNW-directed Caledonian transport of the Moine Thrust (e.g. Barr et al. 1986; Strachan et al. 2010). In Sutherland, a similar WNW-vergent regime occurred, but the thrust geometry of the Moine Nappe is more complex, comprising a number of distinct ductile thrust slices, such as the Ben Hope, Achness, Achiniver thrusts (Holdsworth 1990; Strachan \& Holdsworth 1988; Alsop et al. 2010; Leslie et al. 2010). The overall west-to NW-vergent nature of both D2 and D3 throughout the Moine Nappe is compatible with an overall Caledonian origin (Holdsworth 1990; Strachan \& Holdsworth 1988; Kinny et al. 2003; Holdsworth et al. 2007), and reflect the overall Early Palaeozoic tectonic setting of the region in the sense that the ocean and basins that closed during the Caledonian orogeny lay to the east or SE.

\section{Stratigraphic correlation across the Moine Thrust}

Stratigraphic correlations between Moine and Torridonian rocks on either side of the Moine Thrust have been suggested for a long time (Peach et al. 1907; Peach and Horne 1930; Kennedy 1951; Sutton \& Watson, 1964; Johnstone et al. 1969; Nicholson 1993; Prave 1999) but have remained somewhat controversial (Clough in Peach et al. 1910; Gibbons and Harris 1994; Stewart 2002; Friend et al.2003; Cawood et al. 2004). Krabbendam et al. (2008) demonstrated that the lower Morar Group and Torridon Group in Ross-shire and Sutherland can be correlated on the basis of similar sedimentology, stratigraphy, detrital zircon ages and geochemistry. An important shared feature is the fluvial braidplain depositional environment indentified in the Altnaharra Formation (lower Morar Group) in Sutherland (Krabbendam et al. 2008; Bonsor et al. 2010; 
2012) in the Applecross Formation of the Torridon Group (e.g. Nicholson 1993; Stewart 2002).

However, it remains unclear how Torridonian and Moine units correlate across the southern part of the Moine Thrust, an issue last discussed by Kennedy (1951) and Sutton \& Watson (1964). Both the Morar Group in Knoydart and the Torridon/Sleat groups on Skye contain more stratigraphic units than in Sutherland (Fig. 3). The Sleat Group comprises four formations. From base to top these are: Rubha Guail ('Epidotic Grits’), Loch na Dal, Beinn na Seamraig, Kinloch, (e.g. Peach et al. 1910; Sutton \& Watson 1964; Stewart 2002; Kinnaird et al. 2007). The Sleat Group is absent north of the Torridon peninsula, where the Torridon Group rests unconformably directly upon Lewisian Gneiss (e.g. Stewart 2002).

Sutton and Watson (1964) suggested the following correlation across the southern part of the Moine Thrust :

- $\quad$ Applecross Formation = Upper Morar Psammite Formation;

- $\quad$ Kinloch Formation = Morar Pelite Formation;

- $\quad$ Beinn na Seamraig Formation = Lower Morar Psammite Formation;

- $\quad$ Loch na Dal Formation = Rubha Ruadh Semipelite plus Arnisdale Psammite.

These correlations are problematic in that the Morar Pelite of Knoydart and Morar correlates with the Vaich Pelite in Ross-shire (e.g. Johnstone et al. 1969; then termed Sgurr Mor Pelite): both units contain massive garnetiferous pelite and both overlie thick units of thick-bedded psammite (the Barrisdale Psammite and Altnaharra/Glascarnoch formations respectively) with a relative sharp contact (Ramsay \& Spring 1962; Krabbendam et al. 2011; Bonsor et al 2012). Bonsor et al. (2012) suggested that the base of the Vaich Pelite represents a flooding surface, consequently having an approximate palaeo-horizontal basal contact and a wide geographic extent, thus also likely forming the base to the Morar Pelite. Because the Altnaharra/Glascarnoch formations equate with the Applecross Formation (Krabbendam et al. 2008), it follows that the Vaich Pelite/Morar Pelite occurs above the level of the Applecross Formation, invalidating the correlation proposed by Sutton and Watson (1964). Instead, it is more likely that the Applecross Formation equates with the Barrisdale Psammite. We thus propose the following correlation (Fig. 3):

- $\quad$ Applecross Formation = Barrisdale Psammite;

- $\quad$ Kinloch Formation = Rubha Ruadh Semipelite;

- $\quad$ Beinn na Seamraig Formation = Arnisdale Psammite;

- $\quad$ Loch na Dal Formation plus Rubha Guail Formation = Basal Pelite.

This suggested correlation is supported by:

i) the observation of distinct and well preserved channels and trough cross-bedding in the coarsegrained, thick-bedded Barrisdale Psammite (Fig. 4d, e, f), similar to those observed in the Applecross Formation (e.g. Nicholson 1993; Stewart 2002 );

ii) the generally more fine-grained character of the Arnisdale Psammite (Fig. 4b), with less distinct, more wispy sedimentary structures; similar to most of the Beinn na Seamraig Formation;

iii) the fact that both the Sleat Group and the lower part of the Morar Group below the Barrisdale 
Psammite are present in the south (in Sleat, Knoydart and Morar), but absent in the north (in Torridon, Assynt, Ross-shire and Sutherland), where the Torridon Group and Altnaharra Formation rest directly upon gneiss basement (Stewart 2002; Krabbendam et al. 2008). Whether this absence is due to a bounding fault to the north or to an onlap relationship is difficult to constrain.

Kinnaird et al. (2007) suggested that the Sleat Group has more in common with the Stoer Group than the Torridon Group, and may also have been deposited in a rift setting. The detrital zircon population in the basal Rubha Guail Formation is indeed dominated by Archean zircons (Kinnaird et al. 2007), similar to that of the Stoer Group (Rainbird et al. 2001; Kinnaird et al. 2007), reflecting proximal provenance from the nearby Lewisian gneiss. However, detrital zircons populations in the Loch na Dal and Kinloch formations are dominated by late-Palaeoproterozoic to Mesoproterozoic ages, with little or no Archaean detritus (Kinnaird et al. 2007), showing similarities to detrital zircon populations in the Torridon and Moine successions (Rainbird et al. 2001; Friend et al. 2003; Cawood et al. 2004; Kirkland et al. 2008). This late-Palaeoproterozoic to Mesoproterozoic detritus is clearly distal rather than proximal, reflecting a very different source region than that of the Stoer Group; this is substantiated by the record of distal (exotic) porphyry and rhyolite clasts from higher parts of the Sleat Group (Stewart 2002). Furthermore, the Stoer Group is separated from the overlying Torridon Group by a clear angular (c. $30^{\circ}$ ) unconformity (e.g. Stewart 2002), whereas the Sleat/Torridon contact is a very low-angle unconformity (Kinnaird et al. 2007). Despite a difference in youngest detrital zircon age (possibly the consequence of the low number of zircons analysed by Kinnaird et al. 2007), we suggest that the Sleat group and the lowermost Morar Group are immediate precursors to the more geographically widespread deposition of the overlying Torridon and upper Morar group respectively. This may relate to a change from underfilled to overfilled foreland basin fill (e.g. Miall 1995). The low-angle unconformity between the Sleat and the Torridon group (Kinnaird et al. 2007) may well also exist at the equivalent Rubha Ruadh Semipelite / Barrisdale Psammite boundary, in that the Rubha Ruadh Semipelite thins significantly in southern Knoydart, and appears to be absent in Morar (e.g. Poole \& Spring 1974).

At the moment we propose the correlation between the Sleat Group and the lowermost Morar Group as a hypothesis, which will need to be tested by more detailed sedimentological, detrital mineral and geochemical studies. 


\section{Conclusions}

- The structure of Knoydart is dominated by major west-vergent and west-facing F2 folds developed during peak-metamorphic conditions; in part further tightened by F3 folding under retrograde metamorphic conditions. F2 and F3 folds are broadly co-linear, but not coplanar. The Loch Hourn Anticline is solely an F2 structure, whereas the Morar Antiform is a composite structure, initiated as a regional recumbent F2 fold, further tightened by more upright F3 folding. All F2 and F3 folds verge and face towards the west. The previously mapped Knoydart Slide is here re-interpreted as a local zone of high strain within the Morar Pelite, with the strain gradient caused by a competence contrast across a stratigraphic boundary; this zone has no regional significance. No separate Knoydart Nappe occurs and the Moine Nappe is internally coherent, with no intervening thrust between the Moine Thrust and Sgurr Beag Thrust in Knoydart and Morar.

- Major F1 folds occur at low levels in the structural pile. They form part of a large-scale, originally recumbent isoclinal fold nappe cored by basement gneiss, and with migmatitic Morar Group rocks in its lower limb. Strong shearing occurred locally along the limbs of the F1 fold nappe.

- F2 and F3 are attributed to Caledonian orogenesis, with F2 possibly related to a Late-Ordovician 'Grampian II' phase; the geochronological evidence for Knoydartian orogenesis can be best explained by the F1 fold nappe being Knoydartian in age.

- The upper limb of the F1 fold nappe contains a coherent right-way-up sequence from basement gneiss though the Lower Morar Psammite into Morar Pelite. A correlation between the lower part of the Morar Group and the Sleat Group to the west of the Moine Thrust is suggested: this would represent deposition in a smaller basin followed by more widespread sandstone deposition of the Torridon and upper Morar groups.

\section{Acknowledgements}

John Mendum is thanked for comments on the manuscript. Ian Alsop, Bob Holdsworth and Rob Strachan are thanked for helpful reviews. The authors publish with permission from the Executive Director of the British Geological Survey 


\section{References}

Alsop, G. I., Cheer, D. C., Strachan, R. A., Krabbendam, M., Kinny, P. D., Holdsworth, R. E. \& Leslie, A. G., 2010. Progressive fold and fabric evolution associated with regional strain gradients: a case study from across a Scandian ductile thrust nappe, Scottish Caledonides. In: Law, R., Butler, R. W. H., Holdsworth, R. E., Krabbendam, M. \& Strachan, R. A. (eds). Continental Tectonics and Mountain Building: The Legacy of Peach and Horne. Geological Society, London, Special Publications, 335, 253-272.

Alsop, G. I. \& Holdsworth, R. E., 1993. The distribution, geometry and kinematic significance of Caledonian buckle folds in the western Moine Nappe, northwestern Scotland. Geological Magazine, 130, 353-362.

Bailey, E. B., 1955. Moine tectonics and metamorphism in Skye. Transactions of the Edinburgh Geological Society, 16, 93-166.

Barber, A., 2011. The structure of the Glenelg-Attadale Lewisianoid Inlier and its relationship to the Moine Thrust Zone. Scottish Journal of Geology, 47, 113-132.

Barber, A. J., 2009. Attadale. In: Mendum, J. R., Barber, A. J., Butler, R. W. H., Flinn, D., Goodenough, K. M., Krabbendam, M., Park, R. G. \& Stewart, A. D. (eds). Lewisian, Torridonian and Moine rocks of Scotland. Geological Conservation Review Series, Joint Nature Conservation Committee, Peterborough, 34, 502-506.

Barr, D., Holdsworth, R. E. \& Roberts, A. M., 1986. Caledonian ductile thrusting in a Precambrian metamorphic complex: the Moine of NW Scotland. Bulletin of the Geological Society of America, 97, 754-764.

Bates, R. L. \& Jackson, J. A., 1987. Glossary of geology, American Geological Institute, Alexandria, Virginia.

Bird, A. F., Thirlwall, M. F., Strachan, R. A. \& Manning, C. J., 2013. Lu-Hf and Sm-Nd dating of metamorphic garnet; evidence for multiple accretion events during the Caledonian Orogeny in Scotland. Journal of the Geological Society of London, 170, 301-317.

Bonsor, H., Strachan, R., Prave, A. \& Krabbendam, M., 2012. Sedimentology of the early Neoproterozoic Morar Group in northern Scotland: implications for basin models and tectonic setting. Journal of the Geological Society of London, 169, 53-65.

Bonsor, H. C. \& Prave, A. R., 2008. The Upper Morar Psammite of the Moine Supergroup, Ardnamurchan Peninsula, Scotland: depositional setting, tectonic implications. Scottish Journal of Geology, 44, 1-12.

Bonsor, H. C., Strachan, R. A., Prave, A. \& Krabbendam, M., 2010. Fluvial braidplain to shallow marine transition in the early Neoproterozoic Morar Group, Fannich Mountains, northern Scotland. Precambrian Research, 183, 791804.

Brewer, T. S., Storey, C. D., Parrish, R. R., Temperley, S. \& Windley, B. F., 2003. Grenvillian age decompression of eclogites in the Glenelg-Attadale Inlier, NW Scotland. Journal of the Geological Society of London, 160, 565574.

British Geological Survey, 1971. Arisaig, Scotland, Sheet 61. Solid Edition, One-inch Series. British Geological Survey, Keyworth, Nottingham.

British Geological Survey, 1984. Kintail, Scotland, Sheet 72W. Solid Edition, 1:50 000 Series. British Geological Survey, Keyworth, Nottingham.

Cawood, P. A., Nemchin, A. A., Strachan, R., Kinny, P. \& Loewy, S., 2004. Laurentian provenance and an intracratonic tectonic setting for the Moine Supergroup, Scotland, constrained by detrital zircons from the Loch Eil and Glen Urquhart successions. Journal of the Geological Society of London, 161, 861-874. 
Cawood, P. A., Strachan, R. A., Merle, R. E., Millar, I., Loewy, S., Dalziel, I. W. D., Kinny, P. D., Jourdan, F., Nemchin, A. A. \& Connelly, J. N., in press. Neoproterozoic to early Paleozoic extension and contraction history of East Laurentian margin sequences: the Moine Supergroup, Scottish Caledonides. Geological Society of America Bulletin.

Chew, D. M. \& Strachan, R. A., 2013. The Laurentian Caledonides of Scotland and Ireland. In: Corfu, F., Gasser, D. \& Chew, D. M. (eds). New perspectives on the Caledonides of Scandinavia and related areas. Geological Society, London, Special Publications, 390, 45-91.

Coward, M. P. \& Potts, G. J., 1985. Fold nappes: examples from the Moine Thrust Zone. In: Gee, D. G. \& Sturt, B. A. (eds). The Caledonide Orogen - Scandinavia and related areas, Wiley, Chichester, 1147-1158.

Cutts, K. A., Hand, M., Kelsey, D. E. \& Strachan, R. A., 2009. Orogenic versus extensional settings for regional metamorphism: Knoydartian events in the Moine Supergroup revisited. Journal of the Geological Society, 166, 201-204.

Cutts, K. A., Kinny, P. D., Strachan, R. A., Hand, M., Kelsey, D. E., Emery, M., Friend, C. R. L. \& Leslie, A. G., 2010. Three metamorphic events recorded in a single garnet: Integrated phase modelling, in situ LA-ICPMS and SIMS geochronology from the Moine Supergroup, NW Scotland. Journal of Metamorphic Geology, 28, 249-267.

Dalziel, I. W. D. \& Soper, N. J., 2001. Neoproterozoic extension on the Scottish promontory of Laurentia: Paleogeographic and tectonic implications. Journal of Geology, 109, 299-317.

Freeman, S. R., Butler, R. W. H., Cliff, R. A. \& Rex, D. C., 1998. Direct dating of mylonite evolution; a multidisciplinary geochronological study from the Moine thrust zone, NW Scotland. Journal of the Geological Society of London, 155, 745-758.

Friend, C. R. L., Kinny, P. D., Rogers, G., Strachan, R. A. \& Patterson, B. A., 1997. U-Pb zircon geochronological evidence for Neoproterozoic events in the Glenfinnan Group (Moine Supergroup): the formation of the Ardgour granite gneiss, north-west Scotland. Contributions to Mineralogy and Petrology, 128, 101-113.

Friend, C. R. L., Strachan, R. A. \& Kinny, P. D., 2008. U-Pb zircon dating of basement inliers within the Moine Supergroup, Scottish Caledonides: implications of Archaean protolith ages. Journal of the Geological Society of London, 165, 807 - 815.

Friend, C. R. L., Strachan, R. A., Kinny, P. D. \& Watt, G. R., 2003. Provenance of the Moine Supergroup of NW Scotland; evidence from geochronology of detrital and inherited zircons from (meta)sedimentary rocks, granites and migmatites. Journal of the Geological Society of London, 160, 247-257.

Geological Survey of Scotland, 1909. Lochalsh, Scotland, Sheet 71. Solid Edition, One-inch Series.

Gibbons, W. \& Harris, A. L., 1994. A revised correlation of Precambrian rocks in the British Isles. Geological Society, London, Special Report, 22.

Giletti, B. J., Moorbath, S. \& Lambert, R. S. J., 1961. A geochronological study of the metamorphic complexes of the Scottish Highlands. Quarterly Journal of the Geological Society of London, 117, 233-264.

Glendinning, N. R. W., 1988. Sedimentary structures and sequences within a late Proterozoic tidal shelf deposit; the upper Morar Psammite Formation of northwestern Scotland. In: Winchester, J. A. (ed). Later Proterozoic stratigraphy of the Northern Atlantic Regions, Blackie, Glasgow and London, 17-31. 
Goodenough, K. M., Millar, I., Strachan, R. A., Krabbendam, M. \& Evans, J. A., 2011. Timing of regional deformation and development of the Moine Thrust Zone in the Scottish Caledonides: constraints from the U-Pb geochronology of alkaline intrusions. Journal of the Geological Society of London, 168, 99-114.

Holdsworth, R. E., 1988. The stereographic analysis of facing. Journal of Structural Geology, 10, 219-223.

Holdsworth, R. E., 1990. Progressive deformation structures associated with ductile thrusts in the Moine Nappe, Sutherland, N Scotland. Journal of Structural Geology, 12, 443-452.

Holdsworth, R. E., Alsop, G. I. \& Strachan, R. A., 2007. Tectonic stratigraphy and structural continuity of the northernmost Moine thrust zone and Moine Nappe, Scottish Caledonides. In: Ries, A. C., Butler, R. W. H. \& Graham, R. H. (eds). Deformation of the continental crust; the legacy of Mike Coward. Geological Society London, Special Publications, 272, 121-142.

Holdsworth, R. E., Strachan, R. A. \& Harris, A. L., 1994. Precambrian rocks in northern Scotland east of the Moine thrust: the Moine Supergroup. In: Gibbons, W. \& Harris, A. L. (eds). A Revised Correlation of Precambrian Rocks in the British Isles. Geological Society, London, Special Report, 22, 23-32.

Johnstone, G. S., Smith, D. I. \& Harris, A. L., 1969. The Moinian Assemblage of Scotland. In: Kay, M. (ed). North Atlantic Geology and continental Drift: a Symposium. Memoir, American Association of Petroleum Geologists, 12, 159-180.

Kennedy, W. Q., 1951. Sedimentary differentiation as a factor in the Moine-Torridonian correlation. Geological Magazine, 88, 257-266.

Kennedy, W. Q., 1955. The tectonics of the Morar Anticline and the problem of north-west Caledonian front. Quarterly Journal of the Geological Society of London, 110, 357-390.

Kinnaird, T. C., Prave, A., Kirkland, C. L., Horstwood, M., Parrish, R. \& Batchelor, R. A., 2007. The late Mesoproterozoic-early Neoproterozoic tectonostratigraphic evolution of NW Scotland: the Torridonian revisited. Journal of the Geological Society of London, 164, 541-551.

Kinny, P. D., Friend, C. R. L., Strachan, R. A., Watt, G. R. \& Burns, I. M., 1999. U-Pb geochronology of regional migmatites in East Sutherland, Scotland; evidence for crustal melting during the Caledonian Orogeny. Journal of the Geological Society of London, 156, 1143-1152.

Kinny, P. D., Strachan, R. A., Kocks, H. \& Friend, C. R. L., 2003. U-Pb geochronology of late Neoproterozoic augen granites in the Moine Supergroup, NW Scotland: dating of rift-related, felsic magmatism during supercontinent break-up? Journal of the Geological Society of London, 160, 925-934.

Kirkland, C. L., Strachan, R. A. \& Prave, A. R., 2008. Detrital zircon signature of the Moine Supergroup, Scotland: Contrasts and comparisons with other Neoproterozoic successions within the circum-North Atlantic region. Precambrian Research, 163, 332-350

Kocks, H., Strachan, R. A. \& Evans, J. A., 2006. Heterogeneous reworking of Grampian metamorphic complexes during Scandian thrusting in the Scottish Caledonides: insights from the structural setting and U-Pb geochronology of the Strath Halladale Granite. Journal of the Geological Society of London, 163, 525-538.

Krabbendam, M., Prave, A. P. \& Cheer, D., 2008. A fluvial origin for the Neoproterozoic Morar Group, NW Scotland; implications for Torridon - Morar group correlation and the Grenville Orogen Foreland Basin. Journal of the Geological Society of London, 165, 379-394. 
Krabbendam, M., Strachan, R. A., Leslie, A. G., Goodenough, K. M. \& Bonsor, H. C., 2011. The internal structure of the Moine Nappe Complex and the stratigraphy of the Morar Group in the Fannichs-Beinn Dearg area, NW Highlands. Scottish Journal of Geology, 47, 1-20.

Lambert, R. S. J., 1958. A metamorphic boundary in the Moine schists of the Morar and Knoydart districts of Invernessshire (northwest Scotland). Geological Magazine, 95, 177-194.

Lambert, R. S. J. \& Poole, A. B., 1964. The relationship of Moine schists and Lewisian gneisses near Mallaigmore, Inverness-shire. Proceedings of the Geologists Association, 75, 1-14.

Leslie, A. G., Krabbendam, M., Kimbell, G. S. \& Strachan, R. A., 2010. Regional-scale lateral variation and linkage in ductile thrust architecture: the Oykel Transverse Zone, and mullions, in the Moine Nappe, NW Scotland. In: Law, R., Butler, R. W. H., Holdsworth, R. E., Krabbendam, M. \& Strachan, R. A. (eds). Continental Tectonics and Mountain Building: The Legacy of Peach and Horne. Geological Society London, Special Publications, 335 , 357-380.

May, F., Peacock, J. D., Smith, D. I. \& Barber, A. J., 1993. Geology of the Kintail district: Memoir for 1:50 000 Sheet $72 W$ and part of 71E (Scotland). Memoir of the British Geological Survey, HMSO for the British Geological Survey, London.

McKerrow, W. S., Mac Niocaill, C. \& Dewey, J. F., 2000. The Caledonian Orogeny redefined. Journal of the Geological Society of London, 157, 1149-1154.

Mendum, J. R., 2009. Moine (South) - Introduction. In: Mendum, J. R., Barber, A. J., Butler, R. W. H., Flinn, D., Goodenough, K. M., Krabbendam, M., Park, R. G. \& Stewart, A. D. (eds). Lewisian, Torridonian and Moine rocks of Scotland. Geological Conservation Review Series, Joint Nature Conservation Committee, Peterborough, 34, 547-569.

Miall, A. D., 1995. Collision-related foreland basins. In: Busby, C. J. \& Ingersoll, R. V. (eds). Tectonics of sedimentary basins, Blackwells, 393-424.

Millar, I. L., 1999. Neoproterozoic extensional basic magmatism associated with the West Highland granite gneiss in the Moine Supergroup of NW Scotland. Journal of the Geological Society of London, 156, 1153-1162.

Nicholson, P. G., 1993. A basin reappraisal of the Proterozoic Torridon Group, northwest Scotland Special Publication of the International Association of Sedimentologists, 20, 183-202.

Oliver, G. J. H., 2002. Chronology and terrane assembly, new and old controversies. In: Trewin, N. H. (ed). The Geology of Scotland, The Geological Society, London, 201-211.

Park, R. G., Stewart, A. D. \& Wright, D. T., 2002. The Hebridean terrane. In: Trewin, N. H. (ed). The Geology of Scotland, The Geological Society, London, 45-80.

Peach, B. N. \& Horne, J., 1930. Chapters on the geology of Scotland, Oxford University Press, London.

Peach, B. N., Horne, J., Gunn, W., Clough, C. T., Hinxman, L. W. \& Teall, J. J. H., 1907. The geological structure of the North-West Highlands of Scotland. Memoirs of the Geological Survey of Great Britain.

Peach, B. N., Horne, J., Woodward, H. B., Clough, C. T., Harker, A. \& Wedd, C. B., 1910. The geology of Glenelg, Lochalsh and south-east part of Skye (Explanation of one-inch map 71). Memoirs of the Geological Survey, Scotland, Edinburgh.

Poole, A. B. \& Spring, J. S., 1974. Major structures in Morar and Knoydart, NW Scotland. Journal of the Geological Society of London, 130, 43-53. 
Powell, D., 1966. The structure of the south-eastern part of the Morar antiform, Inverness-shire. Proceedings of the Geologists' Association, 77, 79-100.

Powell, D., 1974. Stratigraphy and structure of the western Moine and the problem of Moine orogenesis. Journal of the Geological Society of London, 130, 575-593.

Powell, D., Brook, M. \& Baird, A. W., 1983. Structural dating of a Precambrian pegmatite in Moine rocks of northern Scotland and its bearing on the status of the 'Morarian orogeny'. Journal of the Geological Society of London, 140, 813-823.

Prave, A. R., 1999. The Neoproterozoic Dalradian Supergroup of Scotland: an alternative hypothesis. Geological Magazine, 136, 609-617.

Rainbird, R. H., Hamilton, M. A. \& Young, G. M., 2001. Detrital zircon geochronology and provenance of the Torridonian, NW Scotland. Journal of the Geological Society of London, 158, 15-27.

Ramsay, J. G., 1958. Moine-Lewisian relations at Glenelg, Inverness-shire. Quarterly Journal of the Geological Society of London, 113, 487-523.

Ramsay, J. G., 1960. The deformation of earlier linear structures in areas of repeated folding. Journal of Geology, 68, 7593.

Ramsay, J. G., 1963. Structure and metamorphism of the Moine and Lewisian rocks in the north-western Caledonides. In: Johnson, M. R. W. \& Stewart, F. H. (eds). The British Caledonides, Oliver and Boyd, Edinburgh, 143-175.

Ramsay, J. G., 2010. West Glenelg and Loch Hourn - Excursion 6. In: Strachan, R., Alsop, G. I., Friend, C. \& Miller, S. (eds). An excursion guide to the Moine Geology of the Northern Highlands of Scotland, Edinburgh Geological Society, Edinburgh, 123-136.

Ramsay, J. G. \& Spring, J., 1962. Moine stratigraphy in the Western Highlands of Scotland. Proceedings of the Geological Association, 73, 295-326.

Richey, J. E. \& Kennedy, W. Q., 1939. The Moine and sub-Moine series of Morar, Inverness-shire. Bulletin of the Geological Survey, Great Britain, 2, 26-45.

Roberts, A. M. \& Harris, A. L., 1983. The Loch Quoich Line-a limit of early Palaeozoic crustal reworking in the Moine of the Northern Highlands of Scotland Journal of the Geological Society of London, 140, 883-892.

Roberts, A. M., Strachan, R. A., Harris, A. L., Barr, D. \& Holdsworth, R. E., 1987. The Sgurr Beag nappe: a reassessment of the stratigraphy and structure of the northern Highland Moine. Bulletin of the Geological Society of America, 98, 497-506.

Rogers, G., Hyslop, E. K., Strachan, R. A., Paterson, B. A. \& Holdsworth, R. A., 1998. The structural setting and U-Pb geochronology of the Knoydartian pegmatites of W Invernesshire: evidence for Neoproterozoic tectonothermal events in the Moine of NW Scotland. Journal of the Geological Society, 155, 685-696.

Sanders, I. S., van Calsteren, P. W. C. \& Hawkesworth, C. J., 1984. A Grenville Sm-Nd age for the Glenelg eclogite in north-west Scotland. Nature, 312, 439-440.

Soper, N. J., Harris, A. L. \& Strachan, R. A., 1998. Tectonostratigraphy of the Moine Supergroup; a synthesis. Journal of the Geological Society of London, 155, 13-24.

Spring, J., 1961. The stratigraphy and structure of the Moine and Lewisian rocks of Knoydart, Invernessshire PhD Thesis, Imperial College, London. 
Stewart, A. D., 2002. The later Proterozoic Torridonian rocks of Scotland: their sedimentology, geochemistry and origin. Geological Society Memoir, 24, The Geological Society, London.

Storey, C. D., 2008. The Glenelg-Attadale Inlier, NW Scotland, with emphasis on the Precambrian high-pressure metamorphic history and subsequent retrogression: an introduction and review. Scottish Journal of Geology, 44, $1-16$.

Storey, C. D., Brewer, T. S., Anczkiewicz, R., Parrish, R. \& Thirlwall, M. F., 2010. Multiple high-pressure metamorphic events and crustal telescoping in the NW Highlands of Scotland. Journal of the Geological Society, 167, 455 468.

Storey, C. D., Brewer, T. S. \& Parrish, R. R., 2004. Late-Proterozoic tectonics in northwest Scotland: one contractional orogeny or several? Precambrian Research, 134, 227-247.

Strachan, R., Smith, M., Harris, A. L. \& Fettes, D. J., 2002. The Northern Highland and Grampian terranes. In: Trewin, N. H. (ed). The Geology of Scotland, The Geological Society, London, 81-147.

Strachan, R. A. \& Holdsworth, R. E., 1988. Basement-cover relationships and structure within the Moine rocks of central and southeast Sutherland. Journal of the Geological Society of London, 145, 23-36.

Strachan, R. A., Holdsworth, R. E., Krabbendam, M. \& Alsop, G. I., 2010. The Moine Supergroup of NW Scotland: insights into the analysis of polyorogenic supracrustal sequences. In: Law, R., Butler, R. W. H., Holdsworth, R. E., Krabbendam, M. \& Strachan, R. A. (eds). Continental Tectonics and Mountain Building: The Legacy of Peach and Horne. Geological Society, London, Special Publications, 335, 231-252.

Sutton, J. \& Watson, J., 1964. Some aspects of Torridonian stratigraphy in Skye. Proceedings of the Geologists' Association, 75, 251-289.

Tanner, P. W. G., 1971. The Sgurr Beag Slide - a major tectonic break within the Moine of the Western Highlands of Scotland. Quarterly Journal of the Geological Society of London, 126, 435-463.

Tanner, P. W. G., 1976. Progressive regional metamorphism of thin calcareous bands from the Moinian rocks of NW Scotland. Journal of Petrology, 17, 100-134.

Tanner, P. W. G. \& Bluck, B. J., 1999. Current controversies in the Caledonides; introduction. Journal of the Geological Society of London, 156, 1137-1141.

Tanner, P. W. G. \& Evans, J. A., 2003. Late Precambrian U-Pb titanite age for peak regional metamorphism and deformation (Knoydartian Orogeny) in the western Moine, Scotland. Journal of the Geological Society of London, 160, 555-564.

Thigpen, J. R., Law, R. D., Loehn, C., Strachan, R., Tracy, R., Lloyd, G., Roth, B. \& Brown, S. J., 2013. Thermal structure and tectonic evolution of the Scandian orogenic wedge, Scottish Caledonides: integrating geothermometry, deformation temperatures and conceptual kinematic-thermal models. Journal of Metamorphic Geology, 31, 813-842.

Van Breemen, O., Pidgeon, R. T. \& Johnson, M. R. M., 1974. Precambrian and Palaeozoic pegmatites in the Moines of northern Scotland. Journal of the Geological Society of London, 130, 493-507.

Vance, D., Strachan, R. A. \& Jones, K. A., 1998. Extensional versus compressional settings for metamorphism: Garnet chronometry and pressure-temperature-time histories in the Moine Supergroup, northwest Scotland. Geology, 26, 927-930. 